\title{
Lung Cancer: A Classic Example of Tumor Escape and Progression While Providing Opportunities for Immunological Intervention
}

\author{
Martin R. Jadus, ${ }^{1,2,3,4}$ Josephine Natividad, ${ }^{1}$ Anthony Mai, ${ }^{1}$ Yi Ouyang, ${ }^{1,2}$ Nils Lambrecht, ${ }^{1}$ \\ Sandor Szabo, ${ }^{2,4}$ Lisheng Ge, ${ }^{1}$ Neil Hoa, ${ }^{1}$ and Maria G. Dacosta-Iyer ${ }^{1,2}$ \\ ${ }^{1}$ Research Service, VA Long Beach Healthcare System, 5901 E. 7th Street, Long Beach, CA 90822, USA \\ ${ }^{2}$ Department of Pathology and Laboratory Medicine, University of California, Irvine, Irvine, CA 92697, USA \\ ${ }^{3}$ Chao Family Comprehensive Cancer Center, UC Irvine School of Medicine, University of California, Irvine, \\ Orange, CA 92868, USA \\ ${ }^{4}$ Health Care Group, Department of Diagnostic and Molecular Medicine, Pathology and Laboratory Medicine Service, \\ VA Long Beach Healthcare System, 5901 East 7th Street, Box 113, Long Beach, CA 90822, USA
}

Correspondence should be addressed to Martin R. Jadus, martin.jadus@va.gov

Received 7 March 2012; Revised 29 April 2012; Accepted 30 April 2012

Academic Editor: Nejat Egilmez

Copyright ( $) 2012$ Martin R. Jadus et al. This is an open access article distributed under the Creative Commons Attribution License, which permits unrestricted use, distribution, and reproduction in any medium, provided the original work is properly cited.

\begin{abstract}
Lung cancers remain one of the most common and deadly cancers in the world today (12.5\% of newly diagnosed cancers) despite current advances in chemo- and radiation therapies. Often, by the time these tumors are diagnosed, they have already metastasized. These tumors demonstrate the classic hallmarks of cancer in that they have advanced defensive strategies allowing them to escape various standard oncological treatments. Immunotherapy is making inroads towards effectively treating other fatal cancers, such as melanoma, glioblastoma multiforme, and castrate-resistant prostate cancers. This paper will cover the escape mechanisms of bronchogenic lung cancer that must be overcome before they can be successfully treated. We also review the history of immunotherapy directed towards lung cancers.
\end{abstract}

\section{Introduction}

Approximately $12.5 \%$ of the newly diagnosed cancers in the world are lung cancers (World Cancer Research Foundation International). Lung cancer leads the world in newly diagnosed cancers: 1.6 million new cases were diagnosed in 2008. In the USA, about 225,000 newly diagnosed patients are annually reported. Bronchogenic lung cancers (LCs) have very fast growth rates. This basic aspect of lung cancer biology makes them sensitive to chemo- and radiation-based therapies for a temporary palliative treatment. These treated lung tumors will eventually relapse because a number of cancer clones or "cancer initiating cells" have escaped the initial therapy. These cells are selected and will return with enhanced resistance to therapeutic modalities. Additional adjuvant treatments are needed to eliminate those remaining cells that survived the initial therapy. Immunotherapy provides the opportunity to destroy the residual lung cancer cells that chemotherapy and radiation miss and may attack the so-called "cancer stem cells." By activating the host immune lymphocytes, these cells can theoretically infiltrate into those remaining pockets of tumor cells and eliminate them. Progress has been made using immunotherapy to successfully improve the survival of some patients with other fatal types of cancer, such as glioblastoma multiforme and castrate-resistant prostate cancer $[1,2]$. Some of the lessons learned from those cancers can be directly applied to cure lung cancer, too.

\section{Derivations of Lung Cancer}

Lung cancers (LCs) are very aggressive tumors derived from different cell types. The incidence of LC in the western world rose precipitously during the 20th century due to increased prevalence of smoking. The prevalence of new lung cancer is dropping in those western countries that 


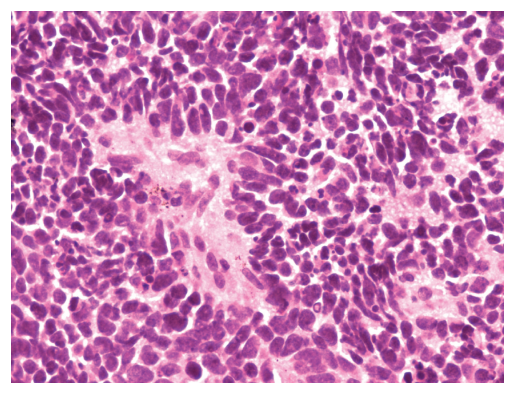

(a)

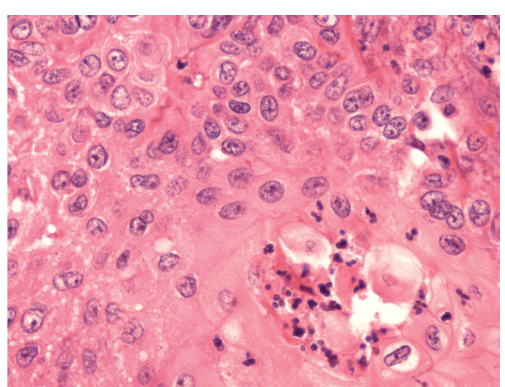

(b)

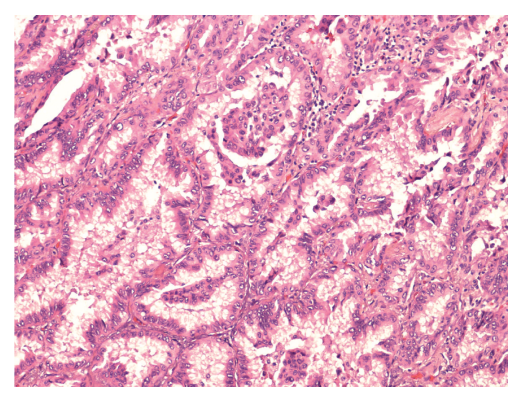

(c)

FIGURE 1: Representative histological micrographs of the most common lung cancers. (a) Small-cell lung cancer taken with a 40x objective lens. (b) Squamous cell lung cancer visualized with a 40x objective lens. (c) Adenocarcinoma lung cancer seen using a 10x objective lens.

successfully discourage smoking; however, the incidence of LC is now rising in those developing countries that see smoking as an easy form of tax revenues. These smokinginduced lung cancers are predominantly caused by Ras mutations. Tobacco smoke contains many carcinogens [3] including very complex aromatic hydrocarbons (benzopyrenes) and other organic compounds such as nitrosamines. The classic example of cancer induction due to chronic carcinogenic exposure usually involves tobacco-derived carcinogens. Once these carcinogens enter healthy cells they induce genetic mutations, which lead to oncogenic transformation. Besides chemical carcinogens, asbestos, radioactive radon, polonium, and plutonium can also contribute to the formation of LC. Finally, there are individuals who can spontaneously develop lung cancer without any known carcinogenic exposures. Asian women, usually of Japanese descent, possess epidermal growth factor receptor (EGFR) mutations $[4,5]$. Some younger men have an echinoderm microtubule-associated protein-like 4 (EML4) and anaplastic lymphoma kinase (ALK) translocation (EML4-ALK) [6, 7], which causes their cancer.

Small-cell lung cancer (SCLC) arises from neuroendocrine cells, the "Kulchitsky cells" of the lungs. These cancers represent about $20-30 \%$ of all lung cancer diagnoses in the USA. This type of lung cancer was previously called "oat cell" cancer. These cells make polypeptide hormones and are characterized by dense core neurosecretory granules. These small-cell lung cancers are different from the non-small-cell lung cancers (NSCLCs). NSCLC includes the adenocarcinomas, squamous and large cell cancers usually arise from alveolar cells. Adenocarcinomas come from basal bronchial cells and type II pneumocytes that arise in the periphery of the lung, while the squamous type lung cancers arise from the bronchial epithelial cells located more centrally. The incidence of squamous lung cancer is dropping in the USA and it has now been overtaken by adenocarcinomas, perhaps due to the reformulation of cigarettes back in the 1970s to contain filters. These filters prevent the larger particulate matter containing the carcinogens from getting into the lungs. The smaller carcinogenic smoke particles still reach into the depths of the lungs. Thus, the percentage of non-small-cell lung cancers (NSCLCs) is now trending towards a more adenocarcinomous type of cancer. The two types of spontaneous lung cancers due to nonsmoking causes are predominantly adenocarcinomas. These types of cancers are thought to be a totally different type of lung cancer when compared to those adenocarcinomas generated by smoking [8].

\section{Pathological Characteristics of Lung Cancers}

Lung cancers are mostly bronchogenic carcinomas. Smallcell carcinoma consists of round, oval, and spindle-shaped malignant small cells with scant cytoplasm, ill-defined cell borders, and finely granular nuclear chromatin. Nuclear molding is prominent. Mitotic count is high and usually presents with extensive necrosis (Figure 1(a)). Squamous cell carcinoma is characterized by infiltrating nests of malignant epithelial cells with keratinization and/or intercellular bridges (Figure 1(b)). Adenocarcinoma typically shows glandular differentiation with acinar, papillary, bronchioalveolar, solid, or mixed pattern with mucin production (Figure 1(c)). Ruffini and coworkers [9] presented data which showed that in situ adenocarcinomas were infiltrated by lymphocytes about $25 \%$ of the time. In contrast, only $5 \%$ of SCLCs had lymphocytic infiltrates. SCLCs have a higher proliferative rate than the adenocarcinomas.

\section{Survival of Lung Cancer Patients}

Because lung cancer cells divide so rapidly, they are temporarily treatable by standard oncological therapies. Localized radiation is applied if the cancer is still physically found within the affected regions of the lung. Adenocarcinomas and squamous cell carcinomas are usually surgically removed as a first step. By the time small-cell lung cancers are discovered they have usually disseminated systemically and so tend to have a poorer prognosis when compared to early detection of NSCLC. Systemic chemotherapy after surgical resection is given. Localized LCs have the best prognoses, whereas metastatic LCs have the worst survival. Lung cancer patients have an overall 5-year survival rate of 16\% (2011 American Cancer Society). The survival statistics indicate that these tumor cells have a variety of escape mechanisms that counteract current therapeutic interventions. These escape pathways include antiapoptosis, drug resistance, and immunodefensive routes. Table 1 shows the various escape Pathways that lung cancers can use and will be discussed in detail. 
TABLE 1: Mechanisms of lung tumor escape.

(1) Antiapoptosis genes

(a) Bcl-2, survivin

(b) Loss of apoptosis effector molecules: caspases, p53 family

(2) Drug resistance genes

(a) Multidrug resistance proteins

(b) CD133

(3) Immunoresistance genes

(a) Soluble factors: PGE, VEGF, TGF- $\beta$, Ido-1, arginase

(b) Immunosuppressive cells: Treg and MDSC

(c) Loss of classical MHC and/or gain of nonconventional MHC

(d) Counterattack: Fas ligand and PD-L/B7-H family members

(e) Age and loss of functional immune system

\section{Escape Mechanisms}

5.1. Antiapoptosis Genes. Radiation and most chemotherapeutic drugs kill tumor cells via apoptosis. Many "cancer stem-like" cells are radio- and chemotherapeutic resistant [10-13]. Lagadec and coworkers [14] showed with breast cancer stem cells that upon radiation treatment reprograms those remaining cells. So when these cancers relapse they will come back with enhanced antiapoptotic gene expression. These altered profiles include increased bcl2, survivin, and livin, which makes these relapsing cancer cells more resistant to drugs that were previously used to treat the initial LC [15-22]. Bcl2 is highly expressed in SCLCs and somewhat less expressed in squamous lung cancers (about one third as much as found in SCLCs), [23]. Survivin is highly expressed in most NSCLCs [21]. These mutations make the cancer cells more resistant to therapy when treatments are given. $\mathrm{Bcl} 2$ and survivin are both induced by $\mathrm{PGE}_{2}[24,25]$ (see Section 5.3.1(a)). Many of these genetic alterations and mutations within LC have been directly attributed to the actions of carcinogens. Joseph et al. observed that SCLC lost production of caspase-1, $-4,-8$, and -10 (apoptosis effector molecules) [26]. It has been postulated that gene silencing via altered methylation profiles $[27,28]$ might be responsible for some of this loss of apoptosis executioner proteins within the SCLCs.

Another type of mutation that frequently occurs within lung cancers would be point mutations within the p53 suppressor gene. P53 mutations within lung cancer lead to upregulation of $\mathrm{Bcl} 2$ while downregulating the pro-apoptotic expression of Bax [29]. Zöchbauer-Müller et al. [30] have reported that SCLCs and NSCLCs both contain these p53 mutations. There are other members of this family (e.g., p63, p73) [31, 32] that perform similar functions as p53. Mutations in these p53 family members prevent apoptosis execution functions, too. Consequently, these mutations prevent tumor cells from killing themselves in response to various therapies.

Apoptosis is called the "silent death." When cells die of classic apoptotic pathways, these dead apoptotic cells tend to be rapidly absorbed or "scavenged" by the adjacent cells.
This prevents the local antigen-presenting cells (APCs) from having sufficient time to absorb this cellular debris in order to stimulate the immune system. In contrast, when cells die of a necrosis-dependent pathway, the immune system is now activated and begins an active immune response in response to the "danger signals" that have been released by the necrotic cells [33-37]. Danger signals include high gel mobility box-1 (HMGB1), uric acid, calreticulin, and the heat shock proteins (HSPs) [38]. Hence, drugs that kill tumor cells via this necrosis induction pathway provide better longterm effects by enhancing the immune system response to the cancer as they regress. There are cytotoxic drugs that can kill tumor cells via apoptosis and stimulate immune responses. A more appropriate terminology has been coined: "immunogenic" versus "nonimmunogenic" cell death to better represent the more nuanced version of this phenomenon $[39,40]$. The judicious use of chemotherapeutic drugs that promote "immunogenic" apoptotic death may further improve chemotherapy against lung cancers by stimulating endogenous immune responses against the tumors.

5.2. Drug Resistance Genes. Another strategy that tumor cells use to evade the full effects of cytotoxic drugs is to export the chemotherapeutic drugs from the cells. Newly synthesized drug-resistant transmembrane proteins actively pump out the chemotherapeutic drugs that have entered into the cancer cell. These exporters effectively reduce the internal concentration of the drug, thereby preventing the full cytotoxic effects of the drug. The small amount of the drugs that remain may even activate cell repair mechanisms such as the cell stress pathways, which would allow heat shock proteins to remove and replace any damaged cellular components. This process may further promote drug resistance by the tumor cells. Lung cancers produce a variety of multidrug resistance proteins (MRPs) and P-glycoprotein [41-43]. In studies by Triller et al. [44] it was shown that when SCLCs relapse there are higher concentrations of MRP3 within the returning cancer cells.

CD133 has been reported to be a marker for various cancer stem cells, including NSCLC [12], although there is a report that their presumed NSCLC stem cells are aldehyde 
dehydrogenase-positive cells [45]. For brain cancers, CD133 is a marker of bioenergetic stress [46] and probably reflects the universal function of this molecule with many different cancer types. CD133 was initially described as a fluorescent dye reverse transporter [13, 47, 48]. Many fluorescent dyes have planar chemical structures that resemble many chemotherapeutic drugs. Therefore, if CD133+ cells are able to export chemotherapeutic drugs via this proposed mechanism, then these stem cells are naturally resistant to chemotherapy. Bertolini and colleagues [12] showed that CD133+ lung cancer cells resisted cytotoxic doses of cisplatinum. By asymmetric division, CD133+ "stem cells" differentiate into CD133-negative cancer cells. These CD133negative cells are subsequently more likely to be killed by chemotherapy. Many early cancer treatments seem to be effective at first, with the bulk of the tumor disappearing. But over time the tumor returns. Thus, the new explanation is that "stem cells" are drug-resistant clones that manage to escape treatment and are responsible for reestablishing the tumor, after the therapy has stopped.

5.3. Immunoresistance Pathways. Lung cancers produce numerous defense strategies that allow them to hide from the immune system. These pathways include releasing soluble immunosuppressive agents, recruitment of suppressor-type cells, lack of immune stimulating molecules, and counterattack strategies.

5.3.1. Soluble Immunosuppressive Mediators. These mediators include prostaglandin (PGE) via cyclo-oxygenase, interleukin-10, other types of type-2 derived cytokines, transforming growth factor- $\beta$, and vascular endothelial growth factor, which inhibit in situ immune responses. These soluble mediators work in a variety of ways and most likely synergize with one other.

(a) Prostaglandin. Lung cancers produce several types of prostanoids and leukotrienes [49, 50], which are derived from arachidonic acid metabolism. Normal lung cells make little to no prostaglandin, whereas lung cancers (squamous, adenocarcinoma, small cell, and mixed lung cancers) produce elevated levels of prostaglandin $\mathrm{E}_{2}\left(\mathrm{PGE}_{2}\right) . \mathrm{PGE}_{2}$ is synthesized by either cyclo-oxygenase-1 (Cox-1) or -2 (Cox-2). Cox-1 is a constitutive enzyme that produces low levels of $\mathrm{PGE}_{2}$, while Cox-2 is the inducible form of the enzyme and produces much more $\mathrm{PGE}_{2}$. Many tumors [51], including lung cancers [52], overexpress the Cox-2 enzyme. Epidemiological studies have shown that a daily dose of aspirin helps reduce $\mathrm{PGE}_{2}$ production and lowers the incidence of a variety of cancers including lung cancers [53]. Prostaglandin $\mathrm{E}_{2}$ can bind to the 4 different prostaglandin receptors: EP1, EP2, EP3, and EP4 [54]. Lung cancer cell lines and in situ lung cancers express a variety of these receptors [55]. $\mathrm{PGE}_{2}$ regulates several aspects of lung cancer biology such as controlling angiogenesis, ERK stimulation, invasion, and proliferation [56-59]. $\mathrm{PGE}_{2}$ raises intracellular cyclic AMP levels $[60,61]$ within various immunocytes, which inhibits dendritic cells and prevents B, T, and NK cell effector functions. (b) Interleukin-10. $\mathrm{PGE}_{2}$ also stimulates IL-10 production from a variety of cell types, macrophages, B cells, and T cells $[62,63]$. Current dogma holds that interleukin 10 is a Th2 cytokine. IL-10 downregulates Th1 immunity (see below) and prevents effective antitumor immunity [64]. But there is a body of evidence which shows that IL-10 can actually assist in antitumor immune responses in a variety of tumor models, including lung cancer [65-67]. Thus, the role of IL10 in tumor rejection is not as clear cut as previously thought and may be a double-edged sword. IL-10 may work in concert with other immunosuppressive agents or suppressor cells to produce protumor effects. LCs are known to produce Th2 polarization by releasing cytokines, IL-4, IL-5, IL-6, and IL-13, besides IL-10 [68-70]. These other cytokines along with $\mathrm{PGE}_{2}$ could either simply mask the effects of IL-10 or synergize with IL-10 to enhance the protumor activities. So a word of caution needs to be applied with IL-10.

(c) Vascular Endothelial Cell Growth Factor. All types of cancers, including lung cancers, make vascular endothelial cell growth factor (VEGF) [71-74]. Some LCs also express the VEGF receptors, suggesting that autocrine loops may control tumor cell growth $[73,75,76]$. VEGF promotes tumor angiogenesis by recruiting endothelial precursor cells from the blood to begin building new blood capillaries. These new blood vessels supply the tumor with oxygen and nutrients allowing the tumor to grow. Vascular permeability functions of endothelial cells are also enhanced by VEGF. VEGF also provides a mechanism by which the immune system is inhibited, by downregulating the functions of antigen-presenting cells (APCs) [77], adaptive immune responses are thereby prevented. The VEGF gene within the general population has several polymorphisms [78]. These polymorphisms may make certain individuals more susceptible to developing lung cancer and may explain why not all smokers develop lung cancer.

(d) Transforming Growth Factor- $\beta$. Transforming growth factor- $\beta \quad($ TGF- $\beta)$ is another commonly overexpressed cytokine that performs multiple functions in tumor biology [79-81]. These activities include assisting tumor growth, improving angiogenesis, enhanced migration, fibrosis production, and increased proteolytic enzyme release, while simultaneously inhibiting the immune response. Lung cancers do overexpress several TGF- $\beta$ isoforms-1, -2 , and -3 while concurrently having mutated TGF- $\beta$ receptors [82-88]. These mutations within the receptors prevent the negative signaling transduction pathways being delivered by TGF- $\beta$ to the tumor cells. Simultaneously, this excess TGF- $\beta$ influences the local microenvironment. TGF- $\beta$ is a well known factor and is very good at inhibiting many aspects of cellular immunity (reviewed in $[89,90]$ ). Like VEGF, there are reported polymorphisms in the TFG- $\beta 1$ that make certain individual less susceptible to developing lung cancer [91].

5.3.2. Immune Suppressor Cells. Many of these immunosuppressive agents listed above will recruit either Treg [91] or myeloid derived suppressor cells (MDSCs) [92]. The combined milieu of all of these immunosuppressive 


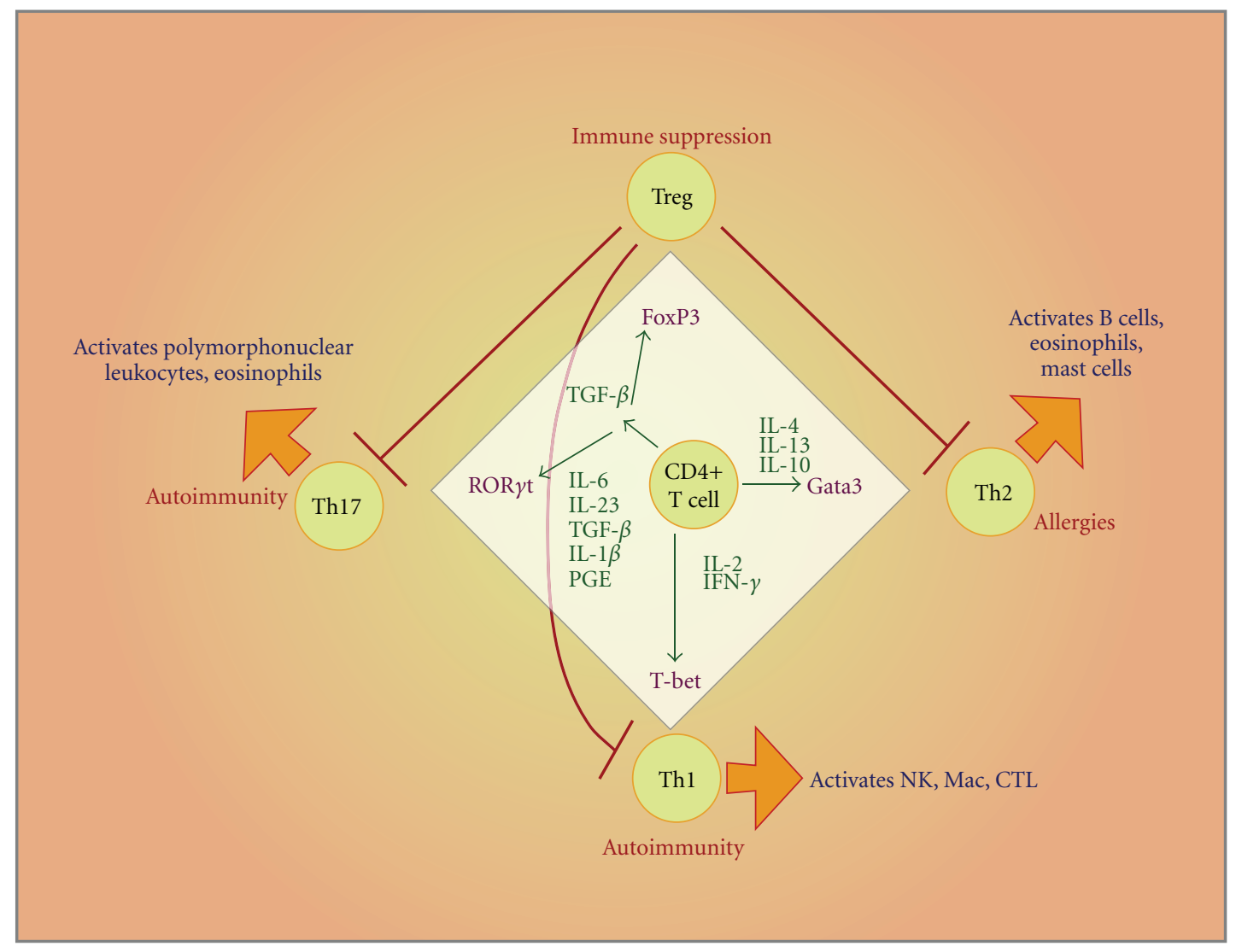

FIGURE 2: The four different types of CD4+ T cells. The different types of CD4 T cells start from common precursor T cells. Upon stimulation with the different cytokines, the naïve CD4+ cells now get to be selected by various transcription factors. Th1 cells become polarized towards this phenotype in response to IL- 2 and IFN- $\gamma$, and the transcription factor, T-bet, now controls the fate of these cells. In response to IL- 4 or IL-13, the Gata3 transcription factor becomes active and Th2 cells result. TGF- $\beta$ now stimulates a common Th17/Treg cell. Upon stimulation with IL-6, IL-23, TGF- $\beta$, IL-1 $\beta$ (in humans), and PGE, Th17 cells become activated through a ROR $\gamma$ T transcription factor. Tregs become polarized by FoxP3. The Tregs have the ability to inhibit Th1, Th2, and Th17 black arrows. The red arrows indicate the effector functions of the various CD4+ subsets. The side effects autoimmunity, allergies, or immune suppression are also noted.

agents can bring about proper conditions that allow these suppressor cells to become the dominant immunologically active cells within lung cancers. The role of these types of suppressor cells is thought to be as a fail-safe mechanism by which the immune system is tightly regulated to prevent autoimmunity or other self-destruction. Lung cancer cells take full advantage of these suppressor cells.

(a) T-Cell Biology. CD4+ T cells can currently be classified into at least 4 different types and each has its own unique function (Figure 2). The different types of CD4 T cells start from common precursor $\mathrm{T}$ cells (so-called naïve or ThP cells). Upon stimulation with the different cytokines, the naïve CD4+ cells are selected by various transcription factors in response to various cytokines or other mediators. Th1 cells become polarized towards this phenotype in response to IL-2 and IFN- $\gamma$ and the transcription factor, T-bet, now controls the fate of these cells. These Th1 cells upon activation will release other cytokines that activate cell-mediated effector functions such as CTLs, NK, and macrophages. These effector cells then eliminate cells infected with either intracellular bacteria or viruses. Th1 cells are believed to play major roles in fighting tumors. In response to IL-4, IL10 or IL-13, the Gata3 transcription factor becomes active and Th2 cells differentiate. Th2 cells activate B cells so that they can make more high-affinity antibodies to help control extracellular bacteria and viruses. The high antibody titers made in response to prophylactic vaccination against these extracellular pathogens are usually attributed to the actions of Th2 cells. Increased IL- 4 and IL- 5 secretion by Th 2 cells stimulates the $\mathrm{B}$ cells into producing $\operatorname{IgE}$ antibody. IgE in turn causes allergies like hay fever. IgE plays an effector role in fighting large extracellular parasites such as helminths.

TGF- $\beta$ stimulates a common Th17/Treg cell. Upon stimulation with IL-6, IL-23, TGF- $\beta$, IL-1 $\beta$ (in humans), and PGE $[93,94]$, Th17 cells become activated through a ROR $\gamma \mathrm{T}$ transcription factor. Upon activation, Th17 cells play an inflammatory role like Th1 but tend to recruit myeloid cells such as neutrophils, monocytes, and macrophages as their effector cells. These myeloid effector cells control extracellular bacteria, parasites, and fungi. Overactive Th17 cells mediate certain autoimmune conditions. Tregs form as a result of the transcription factor, FoxP3, becoming the dominant transcription factor. The Tregs have the ability to 
inhibit the actions of Th1, Th2, and Th17 cells. Tregs are essentially brakes that are thought to inhibit an overactive immune response towards any given antigen. Thus, Treg may be a way that produces immunological tolerance towards self.

(b) Th17 Cells. Th17 cells have been derived from a lung cancer patient who responded to Mage-A3 [95]. Prostaglandin $\mathrm{E}_{2}$ regulates Th17 cell differentiation and if there is an increased amount of $\mathrm{PGE}_{2}$ being produced then the presence of these Th17 cells in lung cancer can be explained [96, 97]. In a mouse model that has a metastatic melanoma of the lungs, Th17 cells promote CTL activity towards the cancer and help clear the tumor [98]. The role of Th17 in cancer biology is still not clear since there are reports that Th17 cells help promote cancer development (reviewed in [99]).

Both Th17 and Treg cells possess Aryl hydrocarbon receptors (AhRs) [100]. Activation of this receptor induces transcriptional regulation that controls these cells functions. Depending upon the exact hydrocarbons used, either Th17 or Treg cells can get activated with differing effects. Since tobacco smoke contains many different hydrocarbons, these receptors can easily activate both cell types. AhR activation on lung-derived fibroblasts also induce Cox-2 expression associated with increased $\mathrm{PGE}_{2}$ production [101], so it is not surprising that an immunosuppressive environment is being established simply by the constant presence of these tobacco-derived hydrocarbons. AhR is expressed and used by human adenocarcinomas [102] to activate the CYP1B1. This $\mathrm{P} 450$ cytochrome enzyme converts noncarcinogens into carcinogens. Presumably, these same enzymes are activated within the precancerous cells that will be eventually turned into tumor cells [103]. AhR can also be found on dendritic cells, and upon activation these dendritic cells have the ability to express indoleamine $2^{\prime} 3^{\prime}$ dioxygenase-1 (IDO-1) [104]. Ido-1 is known to inhibit immune responses (see below).

(c) Tregs. Th17 and Tregs share a common pathway, in that both require TGF- $\beta$ for early development. IL- 6 pushes the development of Th17 cells and IL-23 promotes the growth of already developed Th17 cells. In contrast, Tregs use IL-2 as a growth factor and possess the transcription factor, FoxP3, which drives their maturation and effector function. To eliminate these Treg cells, antibodies towards IL$2 \mathrm{R} \beta$ receptor or a recombinant IL-2-diphteria toxin fusion protein (Ontak, denileukin diftitox) [105] can be used to directly kill these cells and enhance immune responses towards tumors. Besides being an alkylating chemotherapeutic drug, cyclophosphamide also kills Treg cells. Tregs inhibit the immune system in part by possessing membrane TGF$\beta$. Tregs release soluble TGF- $\beta$ [106]. Treg are thought to be important in downregulating the Th1, Th2, and Th17 cells and perhaps preventing autoimmunity. Thus, it is not surprising that Tregs are found in abundance within lung cancers [107-110]. The increased presence of Treg is thought to explain why many therapeutic tumor vaccines do not work as well as they should in many cancer types.

Ido-1 is an enzyme specifically made by Treg. Ido- 1 catabolizes the amino acid tryptophan. Here tryptophan is converted into kynurenine, which limits $\mathrm{T}$ cell responses, either because $\mathrm{T}$ cells require tryptophan to grow through mid-G1 arrest points or one of its metabolites inhibits T-cellmediated functions [111-113]. The role of Ido-1 in immune escape mechanisms has been reviewed in Prendergast [114]. Some human lung cancers produce Ido-1, [115]. In in situ NSCLC, nine out of eleven cancers were Ido-1+ [113]. In a Lewis lung cancer model, Ido-1 was found to be made by the mononuclear cells infiltrating this tumor or by those cells present in the draining lymph nodes [116]. In human lung cancers, Ido- 1 was being made by eosinophils that were infiltrating the NSCLC [117]. Ido-1 expression is strongly stimulated by IFN- $\gamma$ [112]. This finding has significance because CTLs and NK cells could be releasing IFN- $\gamma$. This would inadvertently stimulate a homeostatic feedback loop that would deactivate the immune system via Ido-1. Ido-1 can be inhibited by using D-1-methyl tryptophan [118], an orally taken drug.

(d) Myeloid-Derived Suppressor Cells (MDSCs). Another type of suppressor cell is called the myeloid-derived suppressor cell. These cells have been recently reviewed by several groups [119-121]. These cells are derived from immature granulocytic or monocytic cells. Some of these cells are stimulated by interelukin-3 (IL-3, [122]), granulocytemacrophage colony-stimulating factor (GM-CSF), granulocyte colony-stimulating factor (G-CSF), or $\mathrm{PGE}_{2}$ [123]. Unlike Treg cells, which can be specifically targeted, MDSCs cannot be controlled as effectively since MDSCs are immature myeloid progenitor cells derived from normal hematopoiesis. Drugs are nevertheless being developed to inhibit MSDCs (reviewed in [124]). In a mouse colon cancer model, use of Cox-2 inhibitors can reduce the negative effects of immature MSDCs [125]. Brandau et al. [126] have shown the increased presence of MDSCs in NSCLCs. These MDSCs release enzymes called arginase [127, 128]. Arginase is a family of enzymes that catalyze the breakdown of arginine into ornithine and urea [129]. Arginase 1 is a cytoplasmic enzyme, whereas arginase 2 is a mitochondrial-derived enzyme. Arginine is needed for proper T-cell function and limits the ability of $\mathrm{T}$ cells to respond towards various antigens. Arginine effectively anergizes the T cells thereby making them tolerant towards their environment. Arginine controls immune responses in two opposing ways [130]. Nitric oxide synthase converts arginine into nitric oxide, and this polarizes $\mathrm{T}$ cells, DCs, and macrophages into a cell-mediated (Type 1) pathway. $\mathrm{PGE}_{2}$ induces macrophages into producing arginase 1 , polarizes macrophages into Type 2 cells, and inhibits cell-mediated Th1 immune responses [131]. Additionally, some MDSCs can also produce $\mathrm{PGE}_{2}$ [132] as the way they suppress immune responses.

\subsubsection{Downregulated Major Histocompatibility Complex} (MHC) Makes Lung Cancers Invisible to the T Cells. Lung cancer cells can downmodulate their MHC antigen expression [133-135]. Many lung cancers express very little classic MHC molecules such as HLA-A, -B, or -C. Therefore, $\mathrm{CD} 8 \mathrm{~T}$ cells are unable to recognize any tumor antigens that the cancer cells are expressing in the context of MHC class 1 molecules. This also explains why LCs are rarely 
infiltrated by lymphoid cells [9]. Several pathways have been proposed to explain this loss of MHC expression. Loss of $\beta 2$ microglobulin and loss of transporter of antigen presentation (TAP) molecules [136-138] so that tumor peptides are not loaded successfully onto the MHC are two possible mechanisms to explain this defect. This defect can be corrected by adding cytokines like IFN- $\gamma$ to these cells [139141]. Thus, once activated Th1 cells can infiltrate the in situ tumor and produce IFN- $\gamma$ [141-144]. This released cytokine may fully restore the expression of MHC on the lung cancer cells. However, when good MHC levels are present, beneficial antitumor responses are seen [145].

5.3.4. Increased Expression on Nonclassic MHC: HLA-E, HLA$F$, and HLA-G. Tumors frequently express nonconventional MHC alleles such as HLA-E, HLA-F, and HLA-G (reviewed in $[146,147])$. The exact role of these nonconventional antigens in tumor biology/immunology of cancers is still unknown. These molecules play a major role in preventing immune rejection of developing fetuses during pregnancy. Cancers may also hijack these molecules as a defense against the immune system. It is thought these nonconventional MHCs produce inhibitory type signals to the CTL or NK and prevent immune responses from occurring. Currently, there are reports that HLA-F and -G are expressed by various lung cancers [148-152]. Soluble HLA-G is reported to prevent proper antigen presenting function $[153,154]$. The presence of HLA-E or -G now allows another type of T cells called the $\gamma \delta \mathrm{T}$ cells the opportunity to counter this tumor defense strategy (see Section 7.5).

5.3.5. Counterattack. It is possible that tumor cells can express cell surface molecules, which have the ability to bind to receptors found on immunocytes and induce cell death or anergy. This process is called a counterattack.

Natural killer (NK) and cytotoxic T cells kill target cells via the release of soluble granzymes and perforin. Perforin essentially pokes holes into the target cells membrane and create an osmotic lysis. The released granzymes can enter these holes and bring enzymatic processes that ultimately result in target cell apoptosis. These cytolytic effector lymphocytes also express a membrane protein called Fas ligand. Fas ligand binds to another cell surface called Fas (also known as APO-l and CD95). CTLs can express Fas ligand (CD95L) and kill cells that are Fas+ [155], which can include lung cancers. Ligation of Fas by antibody induces apoptotic cell death in LC cell lines [156]. Niehans et al. [157] found that 16 of 16 human lung cancers (NSCLCs and SCLCs) expressed Fas ligand. Fas is found on many cell types, including $\mathrm{T}$ cells. Ligation of Fas by CTLs, NK or antibodies induces the FADD pathway that leads to caspase 8-dependent apoptosis within Fas+ cells. Two NSCLC cell lines (H2009 and H522) express FasL and have killed the Fas+ Jurkat T cells via a Fas-sensitive mediated cell death pathway [157]. Recently, this concept has been questioned [158]. But Fas ligand also recruits neutrophils into the lung cancers via the production of $\mathrm{PGE}_{2}$ [159]. The recruited cells, including MSDCs, may partially explain the overall effect of the counterattack in situ. Thus, the exact role of FasL in lung cancer still needs to be fully identified.

One-third of primary lung cancers express a soluble decoy receptor, termed decoy receptor 3 (DcR3) [160]. This decoy binds to FasL and appears to inhibit FasL-mediated apoptosis. The fact that many LCs possess this decoy receptor suggests that Fas/Fas ligand must play an important role in lung cancer defense.

\section{Impediments towards Lung Cancer Immunotherapy}

Many arguments can be made against treating lung cancer with immunotherapy. Nonsmokers see this as a cancer that the smokers gave themselves due to their bad habit. Nonsmokers may consequently argue that developing immunotherapy for smoking-related lung cancers is a waste of time when there are many other types of nonsmokingrelated cancers to treat. Hence, research funding is harder to procure for lung cancer. On a biological level, LCs have a variety of defense mechanisms: soluble mediators: transforming growth factor- $\beta$ and cyclo-oxygenase- 2 , which makes prostaglandin $\mathrm{E}$, interleukin-10, and arginase; defensive molecules such as Fas ligand, program death ligand-1 (B7-H1), nonconvention HLA molecules, lack of major histocompatibility (MHC) class I molecules, and recruitment of suppressor type cells. All these obstacles can naturally limit immune responses towards these cancer cells. These same arguments were also made against the immunotherapy of malignant human gliomas [161]. But progress is now being made against gliomas using dendritic cells pulsed with the patients' autologous cancers and other immunotherapies $[1,162,163]$. Thus, the development of immunotherapy towards lung cancer is significantly behind that observed with other types of immunotherapy for cancer.

\section{Immunotherapy against Lung Cancers and Opportunities for Intervention}

7.1. Early Steps. Since the beginnings of modern medicine, doctors have been looking for the "magic bullet" to treat tumors, whether it is through drugs, surgery, radiation, or other modalities. Back in the late nineteenth century William Coley discovered that a number of cancer patients who simultaneously had bacterial infections sometimes had miraculous cures to their cancers. He later used the bacteria isolated from those miraculous cures as toxins and his treatment was known as "Coley's toxins." Many explanations are possible, that is, released cytokines (IFN$\gamma, \mathrm{TNF}), \mathrm{CpG}$ segments of the bacterial DNA, and bacterial cell wall products, like LPS, can activate the tolllike receptors (TLRs) found on immunocytes, and so forth. Thus, biological response modifiers can enhance oncological therapies. Bacillus Calmette Guerin (BCG) was initially proved to be effective at treating superficial bladder cancer [164]. Injecting these bacteria into bladder cancers is now a routine therapy. This induced inflammation not only kills the tumor, probably by activating the innate immune system, 
TABLE 2: Types of immunotherapy for lung cancer.

(1) Active vaccination: subunit vaccines from tumor lysates

(2) Passive antibody administration

(a) Direct tumor binding: various tumor antigens

(b) Indirect approaches: anti-VEGF, anti-CTLA-4 anti-PD-1/PD-L1, and anti-Treg

(3) Passive cell-mediated administration

(a) LAK cells

(b) TIL/draining lymph nodes T cells

(c) $\gamma \delta \mathrm{T}$ cells

(4) Gene therapy
(a) IL-4
(b) GM-CSF
(c) MHC and/or costimulator molecules
(d) TGF- $\beta$ knockdown

(5) Dendritic cell vaccination
(a) Peptides
(b) Tumor lysates

but also leads to sustained immune responses by activating the local antigen-presenting cells. BCG was tried to treat lung cancer but failed to show any responses [165-167]. Two other therapies such as using Corynebacterium parvum [168] and Mycobacterium vaccae [169] have been tried with lung cancers. Both of these therapies initially seemed to fail. However, when the data concerning the Mycobacteria vaccae was reevaluated, there was a higher survivor rate in patients who successfully completed the therapy than in those who did not [170]. Since compliance was a major issue with this therapy, it probably mean that many toxicities were occurring. The consequences of these toxicities probably means that it cannot be developed any further. Table 2 summarizes the various types of lung cancer immunotherapy that are currently being used to treat lung cancers.

Hollinshead et al. [171] showed significant 5-year survival rates for all types of lung cancer patients treated with a tumor antigen subunit vaccine purified from different types of lung cancers. The cancer vaccine was made by isolating the tumor antigens by an affinity chromatography technique using a variety of antibodies directed towards the antigens found on lung cancers. The 5-year survival of 234 treated patients with stage I and II patients was 69\%, compared with $49 \%$ of the untreated controls. Unfortunately, this work did not proceed, despite its early promising success, since this vaccine was deemed dangerous. This vaccine was made with Freund's Complete Adjuvant (FCA), which contains mycobacterial proteins. These bacterial proteins stimulate the innate immune system via toll-like receptors (TLRs). The protocol included 3 vaccinations a month apart with FCA. FCA causes severe immune reactions and has painful reactions. Tissue damage such as ulceration is one potential sequela. These toxicities probably limited the further use of this promising protocol. This work did indicate that active immunotherapy can successfully treat some LC patients.
7.2. Direct Antibody Therapies. In the mid-1970s, Kohler and Milstein created hybridoma technology, which led to the creation of monoclonal antibodies. In the early to mid 1980s, this technology was commercialized for generating clinically applicable antibodies. Monoclonal antibodies were used to directly treat cancers early on. These antibodies were thought to be the "magic bullets" that could kill tumor cells. The advantage was that these antibodies could be easily scaled up, because they were derived from immortalized hybridoma cell lines. These antibodies could be used alone as unmodified antibodies to allow antibody-dependent cytotoxicity (ADCC) to occur. These antibodies could also be conjugated with radioisotope, chemotherapeutic drugs, or with cytokines or enzymes to target the cancer. Monoclonal antibodies are very unique to the tumor and it was thought they should only home towards the tumor and thereby limit toxicity to other cells. However, in retrospect, antibodies do not penetrate deeply within the tumor bed since they bind more heavily to the peripheral tumor cells that are initially exposed to the antibody.

The CC49 monoclonal antibody, which binds to a tumorassociated glycoprotein 72 (TAG-72), has also been tried in conjunction with radioisotopes [172]. Antibodies directed towards a cell surface ganglioside, called GD3, are being tried. GD3 is highly expressed in SCLC, but not in NSCLC. $\mathrm{Bec} 2$ is an anti-idiotypic antibody that binds to the idiotype of the antibody against GD3 and so it is thought to be a mimic of GD3. This antibody was combined with a BCG adjuvant to treat SCLC. These clinical studies against SCLC proved to be somewhat positive when compared to historic controls [173]. A similar approach was taken towards a Neuglycosylated sialic acid ganglioside, called NeuGc-GM3, that is found on all types of LC. The anti-idiotypic antibody was called 1E10. This antibody was tried in both SCLC and NSCLC [174]. A survival benefit of about 6 months was 
noted in those patients that developed immunity against NeuGc-GM3.

The first antibody (early 1990s) that seemed to have any major clinical effect against any type of cancer was the herceptin (Trastuzumab) antibody, which targets the her $2 /$ neu surface protein that was heavily overexpressed on some breast cancers [175]. At the time of its initial discovery, it was thought that this antibody would simply bind to a surface protein found on the cancer cell. Afterwards, it became apparent that the success was due to the fact that this antibody was interfering with a key cell-signaling pathway that prevented a growth factor signal pathway from being activated on the her $2+$ cells. The fact that this antibody also allowed antibody-dependent cell cytotoxicity (ADCC) probably helped its therapeutic efficacy [176]. So the takehome lesson is that it is vital to target a key biological factor that controls a unique aspect of the tumor and not just target any random cell surface tumor protein. Thus far, no antibody that directly targets an equivalent function of her2 on LC has been found. However, the creativity of medical scientists and the versatility of antibodies have allowed certain antibodies to be developed that enhance results to cancer to be developed and used in an indirect method (see Section 8).

7.3. Lymphokine-Activated Killer (LAK) Cells. Later immunotherapy studies focused on using a variety of other more advanced ex vivo cellular techniques, such as using lymphokine-activated killer (LAK) cells, cytotoxic T lymphocytes (CTLs) derived from tumor infiltrating lymphocytes (TIL) cells or from draining lymph nodes. The hope here was to generate overwhelming numbers of effector lymphocytes in vitro that could be applied in vivo. The genetic revolution of the 1980s and 1990s provided cancer immunologists with the opportunities to acquire sufficient amounts of cytokines and growth factors to stimulate the immune system on a large clinical scale. Some of the early cytokines that were genetically cloned and tested therapeutically were interleukin-2 (IL-2) and tumor necrosis factor (TNF). LAK cells became very popular in the mid-1980s. Human peripheral blood lymphocytes upon stimulation with IL-2 (a lymphokine known back then) turn NK and CD8+ T cells into nonspecific killer cells that lyse tumor cells in vitro [177]. When the cells were infused back into the patient, a clinical response was sometimes observed against melanomas and renal cancers [178]. One severe limitation of this therapy was that systemic toxicities occurred in many patients and this prevented many recipients from completing their therapies. This was perhaps due to the cytokines the LAK cells released such as TNF or IFN- $\gamma$. Enthusiasm for this modality also ran out when it became apparent that clinical responses were equally found when IL-2 was just administered in vivo alone without having to go through the laborious LAK cell collection and processing protocols [179]. Even though lung cancer cells were nonspecifically killed in vitro, LAK therapies with lung cancer patients largely failed. The review by Al-Moundhri and colleagues [180] covers the results of LAK therapy with lung cancers that was acquired from the 1980s.
Attempts were also made where advanced NSCLC patients were directly injected with IL-2 and TNF intratumorally [181]. This was a method of stimulating endogenous LAK cell precursors already within the tumor. Most patients experienced severe toxicities. Three patients had partial or stable disease that only lasted 6-9 months, but 1 patient with severe metastatic disease did live for at least 30 months [182].

\subsection{Tumor Infiltrating Lymphocytes (TILs) and Draining} Lymph Node (DLN) T Cells. The next great hope for immunotherapy involved isolating and expanding the tumor infiltrating lymphocytes (TILs). One early murine study fueled support for this concept [183]. This approach was novel because both CD4+ and CD8+ T cells could be isolated and expanded. The theory was that these lymphocytes should be specific for the tumor since they were already present within a tumor. This occurred in the days before the importance of antigen presentation by dendritic cells was known (see Section 7.6). It was observed that $\mathrm{T}$ cells needed to be "antigen-dosed" every 2 weeks or so, otherwise these $\mathrm{T}$ lymphocytes lost antigen specificity. There is a paucity of lymphocytes within many lung cancers [9]. So a derivative of this TIL approach was to take the lymphocytes from the tumor draining lymph nodes (DLNs) and expanding those cells ex vivo as you would do with the TIL. Both TIL and DLN cells were viewed to be very tumor specific and would have less toxicity than the LAK cells. Occasionally, these types of cells could have antitumor immune responses against cancers including lung [184, 185], but in most cases these cells did not work. With the subsequent discovery of Treg cells, the presence of these Tregs now explains why many of these TILs and DLNs expanded cells did not work as well as they were hoped because they were selectively enriched for Treg using the IL-2 (see Section 5.3.2(a)).

However, a big advance came about when it was discovered that if nonmyeloablative treatment was given to cancer patients before they received TIL cells, better clinical responses were seen [186]. Here other lymphocytes were killed, including Treg and other non-tumor-specific $\mathrm{T}$ cells. This mass killing of these lymphocytes then provided niches for these reinfused ex vivo expanded cells [187].

7.5. $\gamma \delta \mathrm{T}$ Cells. Another $\mathrm{T}$ cell type also matures in the thymus, besides the classic $\alpha \beta$ T-cell receptor (TCR) rearranged T cells. These cells instead use a rearranged $\gamma \delta$ TCR to recognize their antigens. These $\gamma \delta \mathrm{T}$-cell receptors have a very restricted TCR diversity but are not MHC restricted. These cells may recognize nonclassic HLA-E and HLA-G molecules through NKG2D or $\mathrm{V} \gamma 9 \mathrm{~V} \delta 2$ receptors. These lymphocytes were initially discovered to be cytotoxic towards leukemia cells. Wrobel and colleagues [188] discovered that these cells also had the ability to recognize and kill NCSLC lung cancer cells in vitro. Several of the ligands that $\gamma \delta \mathrm{T}$ cells can recognize are MICA, MICB, ULBP-2 and ULBP-3 binding proteins found on the lung cancers [188]. Groh and colleagues [189] showed that in situ lung cancers possessed some ligands that $\gamma \delta \mathrm{T}$ cells recognized; these $\gamma \delta$ cells were found in situ with the lung cancers. This non-MHC-restricted killing by $\gamma \delta \mathrm{T}$ cells opens up 
the possibility that allogeneic donors could be used for therapeutic purposes in lung cancers without risking the possibility of graft versus host reactions or autoimmune diseases. Clinical trials using $\gamma \delta \mathrm{T}$ cells against recurrent NSCLCs are beginning to appear [190]. Ten patients were expanded with their autologous $\gamma \delta \mathrm{T}$ cells, the median survival of these treated NSCLC patients was 401 days. Thus, this adoptive form of immunotherapy was deemed safe.

7.6. Gene Therapy. Gene therapy became the next big topic for a decade starting in the early/mid-1990s. The seminal work of Dranoff and colleagues [191] showed that immunemediated rejection was not the same as generating longlasting immunity. When living B16 melanoma cells were transduced with IL-2 or TNF and injected into mice, no tumor growth occurred as a result of CTL and NK becoming activated by those released cytokines. In contrast, IL-4- or GM-CSF-transduced cancer cells formed tumors when injected subcutaneously. However, if the IL-4 or GMCSF transduced cells were irradiated and then used as a prophylactic vaccine, long-term memory was generated against the unmodified B16 tumor cells. Mice that rejected the IL-2- or TNF-transduced B16 melanoma cells showed no lasting recall memory, even though an immune response rejected the initial IL-2- or TNF-transduced tumor cells. Later it was realized that the released IL- 4 and GM-CSF stimulated/recruited a poorly understood cell, which at the time was called the dendritic cell (DC). Today dendritic cells are considered the best antigen-presenting cells in the body. DCs can stimulate both naïve and previously activated $\mathrm{T}$ cells. This genetic engineering work produced a major paradigm shift that revolutionized our concepts in cancer immunology and has opened up the possibility of using immunotherapy against many different types of cancers.

Lung cancer vaccines transduced with various cytokines and costimulatory molecules have been used clinically. GMCSF-transfected lung cancer cells used as vaccines are the most commonly used ones. Salgia et al. [192] was the first to use an autologous NSCLC tumor cells were transfected with an adenovirus that delivered GM-CSF. They used this in $97 \%$ of their patients. Here the tumor cells were isolated and transfected with adenoviruses. Two of the treated patients were noted to have been disease-free for $42+$ months. A larger study was later run and was known as a GVAX approach [193]. The transduced cancer cells are irradiated and then used as a whole-cell vaccine. The longest surviving patients were noted to have received the most cells, which also had the highest expression of GM-CSF. A follow-up trial, called the allogeneic GVAX approach (allo-GVAX or Bystander GVAX) [194], was performed where allogeneic K-562 cells, which secreted much more GM-CSF than the autologous lung cancer cells, were combined with unmodified lung cancer cells. The results proved to be negative in terms of patient responses towards the cancers. One possibility is that this elevated dose of GM-CSF induced MDSC, which hindered antitumor immunity (see Section 5.3.2(d)). In conclusion, using autologous lung cancer cells that were transfected with the GM-CSF was the most beneficial vaccine.
Another genetic approach was to engineer lung cancer tumor cells with either HLA-A1 or HLA-A2 MHC molecules along with the immune costimulatory molecule, CD80. The idea here was to use a whole cell line (AD100) that expressed more MHC class 1 with the costimulatory molecules [195] to stimulate endogenous $\mathrm{T}$ cells directly by the vaccinated cells. Of their 18 patients tested, the median survival time was 18 months. No differences were noted in the responses of their patients to HLA compatibility, so this finding suggests that cross-presentation of tumor antigens was occurring, so HLA matching of the vaccinating tumor with the patient was not necessary to generate clinical responses.

A different genetic approach was taken with the canary pox virus. Here the virus genome was modified so that it would deliver a lung cancer antigen called the carcinoembryonic antigen (CEA) along with the B7.1 costimulatory molecule. This construct was called the ALVAC [196]. CEA is overexpressed in roughly $70 \%$ of NSCLC. This vaccine was injected intramuscularly every 4 weeks for 3 months into lung adenocarcinoma patients. No toxicities were seen with the highest doses of the virus given. Three patients had stable disease that correlated with CEA-specific T cells that produced IFN- $\gamma$. This project did not proceed any further with lung cancer but seems to be proceeding further with colon cancer.

CEA is used as a tumor vaccine with the common yeast, Saccharomyces, being used as the delivery vehicle. GlobeImmune (Louisville, Colorado) has pioneered this "Tarmogen" approach. Their clinical product is called GI6207 and is used with metastatic adenocarcinomas. A phase 1 study enrolled 25 patients with three doses, which was administered at 4 sites subcutaneously biweekly for three months then monthly until disease progression. Twenty percent of the patients had stable disease and had declines in serum CEA levels [197].

The Mucin-1 (Muc-1) antigen is a core peptide of a glycoprotein found on many epithelial cancerous cells, including NSCLC. Muc-1 is thought to play several roles in cancer including loss of immune recognition, tumor cell migration, and resistance to apoptosis [198]. The attenuated Ankara strain of vaccinia virus was genetically engineered to transduce the Muc-1 antigen along with the IL-2 gene to create the "TG4010" vaccine. The vaccine was administered weekly by subcutaneous injections at the dose of $1.0 \times 10^{8}$ PFU and then once every 3 weeks until disease progression. There was an improved clinical outcome with TG4010 in patients, especially in those having T lymphocytes displaying an activated NK phenotype [199, 200]. The higher levels of activated $\mathrm{T}$ lymphocytes also correlated with longer TG4010 patient survival than the chemotherapy alone controls. In addition, increased circulating IFN- $\gamma$ levels predicted a longer survival for the TG4010-treated patients.

7.7. Peptide Vaccine. A number of tumor-associated antigens have been discovered in lung cancers. Van der Bruggen et al. [201] have compiled a listing of various tumor antigens that have been found within human lung cancers. These tumorassociated antigens are composed of mutations, shared tumor-specific, differentiation, and overexpressed antigens. 
These antigens could be possible antigens used for lung cancer immunotherapy.

A synthetic 25-amino-acid Muc-1 peptide was formulated into a liposome and is called L-BLP25 or Stimuvax [202]. This immunogen is now being used as a vaccine in NSCLC. The vaccine was injected into patients that received a single dose of cyclophosphamide. Sixteen of 65 patients demonstrated a T-cell immune response, and the patients had median survival time of 30.6 months compared to 13.3 months with the best supportive care.

The Wilms tumor antigen-1 (WT-1) is found within most NSCLCs and SCLCs [203]. Oka and colleagues [204] used a 9-mer of WT-1 (which is restricted for the HLA-A2402 allele) and emulsified it with the montanide ISA51 adjuvant. They administered this vaccine three times at 2-week intervals to breast, leukemia, and lung cancer patients who were HLA-A2402 positive and had WT-1-positive tumors. Three of the 10 lung cancer patients showed an immunological response as defined by a positive tetramer staining profile along with elevated intracellular IFN- $\gamma$ expression. One patient has managed to survive the lung cancer and has been repeatedly vaccinated during this time ( $>2+$ years).

Cyclophilin B was found on lung cancer adenocarcinomas and can be a target of CTLs [205]. Gohara and colleagues [206] used a cyclophilin-based peptide vaccine. Peptides were mixed with incomplete Fruends adjuvant (IFA) and injected as a subcutaneous vaccine in a phase I study in Japan. No significant increases in cellular responses were seen and this study was deemed to have failed.

The Mage-A3 peptide coupled with the AS02b adjuvant was tried in 182 patients that were Mage-A3+ NSCLC $[207,208]$. This trial was using the GlaxoSmithKline MAGE-A3 protein. Some trends suggested beneficial results occurred and prompted further studies. These positive results initiated the development of the GSK1572932A study (ClinicalTrials.gov) and is part of the MAGRIT (MAGEA3 Adjuvant Non-Small-Cell Lung Cancer Immunotherapy) study [209]. This study was opened in 2007 and is now closed to enrollment. This vaccine was composed of 13 intramuscular injections of the vaccine. Survival statistics are currently being collected to determine if these results are truly significant.

The IDM-2101 composite vaccine is made by IDM Pharma (Irvine, CA). This synthetic peptide vaccine is based upon 10 different HLA-A2-restricted epitopes against 5 different antigens (CEA, p53, Her2, Mage-2, and Mage-3 antigens along with a pan-DR epitope). A phase II study was done [210]. Survival was longer (17.3 months) in patients demonstrating an immune response to epitope peptides $(P<.001)$ than those not immunologically responding. One patient had a complete response to the vaccine.

Epidermal growth factors (EGFs) are frequently overexpressed in LC and their receptors are frequently mutated within LC [211]. Hence, small chemical inhibitor strategies are targeted to the EGFR pathways and are frequently used in LC [212]. In this vaccination strategy, a recombinant fusion protein of EGF was conjugated to a bacterial P64K protein as a carrier protein to induce immune responses. As a result of this vaccination there was an increased titer of circulating anti-EGF antibody titers. This also correlated with a decreased level of serum EGF. They also made a direct correlation between antibody responses with patient survival, especially in those patients younger than 60 years old. This age response is very important, since as people age their immune responsiveness decreases. So vaccination may not be effective for individuals older than this age [213]. The data from 3 studies was complied in a meta-analysis and confirmed the study above [214].

7.8. Dendritic Cell Vaccines. Most smoking-related cancers have p53 mutations. DC-based vaccinations were based on infecting DC with p53 transfecting adenoviruses [215]. In vitro, when these transfected DCs are activated they can generate CTLs versus p53 [216]. These trials showed some progress. Introgen Therapeutics (Austin, Tx) in collaboration with the previous group is developing this concept with the INGN225 vaccine just with the p53 gene. In SCLC, this therapy induced a significant immune response and sensitized the SCLC to subsequent chemotherapy [217].

Hirschowitz and coworkers have developed an allogeneic 1650 adenocarcinoma cell line that was characterized for expression of Her2/neu, CEA, WT-1, Mage2, and survivin. They used these apoptotic cells to load immature autologous CD14+ monocytic DC stimulated with GM-CSF/IL-4. These DCs (80-90 million DCs) were injected as an intradermal vaccine to stimulate the immune system in a variety of stage IA to stage IIIB NSCLC patients [218]. Antigen-specific immune responses were noted in this study in the majority of the 16 patients tested. A follow-up study of these patients along with 14 new patients was reported 3 years later [219]. Many of these patients were still alive, although it was not clear whether these positive responses were due to good surgical resections or due to immunotherapy.

Dendritic cells are beginning to be developed as a therapy in China, which are pulsed with the Xage-1b protein [220]. Xage- $1 b$ is a member of the cancer-testis family of antigens and is overexpressed in many lung cancers. In early studies, this methodology does generate CTLs in vitro and has the ability to kill lung cancers, but not normal lung cells. Thus, this antigen might be added to the tumor antigen armaments towards lung cancer.

Tumor lysates derived from autologous NSCLCs are being electroporated into dendritic cells in Korea. These DCs were then injected into advanced NSCLC patients. In these early studies, Um and coworkers [221] showed that when their patients received the most dendritic cells (12 million cells) 3 times at 2 -week intervals, five out of the nine patients resulted in increased IFN- $\gamma$ production after an in vitro restimulation. Two of the patients treated with these cells appeared to have some beneficial effects. So getting tumor antigens into dendritic cells can be effectively done in a couple of ways.

When people view tissue culture cells under the microscope, one can frequently see remnants of cells, left as a cell moves away. These released cell-debris particles are called exosomes. These exosomes contain all the small material as the cell that produced them, proteins, RNA, microRNA, and so forth, including tumor antigens. Some 
of these exosomes when formulated with CpG adjuvant and injected into animals can create immune responses towards the original tumor [222]. This intriguing observation was followed up when exosomes from mature dendritic cells were used as the vaccine [223-225]. This work has now been developed into a clinical modality for treating NSCLC at the Institut Gustave Roussy in France. Drs. Besse and Chaput are spearheading this approach. In this trial autologous DCs are being loaded with HLA-DP04-restricted MAGE-3, and HLAA02-restricted peptides NY-ESO-1, MAGE-1, MAGE-3 and MART-1. So far, no results of this clinical effort have been reported.

7.9. Knockout Strategies. The advantage of using a whole cancer cell is that the entire spectrum of tumor antigens can be harnessed against the tumor; all these antigens can now stimulate multiple clones of T cells. This contrasts with vaccination strategies that only use a few antigens, such as the peptide vaccines or adenoviruses transfecting tumor antigens. For immune responses to occur, APC must take up the antigen and chop it up via the DC proteosome. These digested peptides should then be presented via the patient's own DC and stimulate the host T cells. In theory, any tumor cell could be used to vaccinate the patient, regardless of the patient's HLA profile, as the Raez et al. study [195] seems to show. NovaRx (San Diego, CA) has genetically knocked down TGF- $\beta_{2}$ expression and is using a combination of 4 allogeneic cell lines (lucanix also known as belagenpumatucel-L) as a vaccine [226]. Since TGF- $\beta$ is prevented from being made, when these killed tumor cells are taken up by the DCs they should respond maximally, since no endogenous TGF- $\beta$ was present to hinder DC function. Hence, better immune stimulation should occur. Early results in a phase II study do suggest the vaccine is well tolerated. It also generated T cell reactivity in 11 of 13 of these treated lung cancer patients. As a result, survival of these immune responding patients was 32.5 months compared to 11.6 months with the nonresponders. Thus, allogeneic cells do seem to show they can act as an effective immunogen, although it is still really too early to make it an established fact.

\section{Antibodies That Can Augment Immune Responses}

In contrast to antibodies being used to directly treat the cancer, antibodies can create positive clinical responses in other ways. One strategy of antibodies is to either use them as an antiangiogenic approach or use antibodies (anti-CTLA-4, anti-PD-1/PD-L1, and anti-IL-2 receptors) to inhibit some of the negative regulatory pathways. The former antibody therapy is beginning to show clinical responses in many cancers, including NSCLC, while the later antibodies may be added to other therapies as discussed earlier. These combined therapies could have a potentially big impact on lung cancer immunotherapy. So far, none of these approaches has been reported with lung cancer. But we anticipate we will see more of these types of studies in the near future.
8.1. Bevacizumab Is an Anti-VEGF Antibody Developed by Genentech. VEGF, as described in Section 5.3.1(c), cannot only play a role in tumor angiogenesis by working on the tumor recruitment of endothelial cells but may also play a role in breaking autocrine loops in LC. VEGF can inhibit immune responses by turning off the actions of dendritic cells. Bevacizumab has recently been approved by the US FDA as a first-line therapy for metastatic colorectal cancer. And it also does appear to be effective against other human cancers, too [227]. In a phase 3 study done with metastatic NSCLC patients, there was increased progressionfree survival $(P<0.0001)$. Additionally, there was a better overall survival (12.5 months compared to 10.2 months) with a $P<0.007$. So some progress is now being made against lung cancer using this antibody.

8.2. Ipilimumab Is the Antibody That Targets an Immunomodulatory Molecule Called CTLA-4. As T cells become activated into effector cells, they are induced to express CTLA-4 antigen, which is capable of binding to the costimulatory molecules found on DC, CD80, and CD86. CTLA-4 binds better to the CD80/CD86 molecules than does the immunostimulatory CD28 receptor found on the $\mathrm{T}$ cells [118]. Negative signals are delivered to the $\mathrm{T}$ cells upon binding to APC CD80/CD86 molecules via CTLA-4 and the T cell is essentially inhibited from further functional activities. These $\mathrm{T}$ cells will eventually be eliminated via apoptosis. Both natural and induced Tregs also use CTLA-4 (cytotoxic $\mathrm{T}$ lymphocyte antigen-4) to inhibit immune responses by inhibiting APC function. Antibodies towards CTLA-4 such as ipilimumab are being developed to inhibit this pathway to improve tumor vaccines in humans. This antibody is now being used in NSCLC [228]. By preventing this CTLA-4mediated downregulation, an enhanced immune response can be made and can probably enhance antitumor immune responses. Recently, this antibody has been successfully used for the treatment of melanoma [229]. Here, additional, four months of survival were noted in these patients. In general, these antibodies have to be carefully watched since they have the potential to cause autoimmunity and produce other severe effects that limit their therapeutic ability.

8.3. Another Family of Antibodies Is Directed towards the Family of PD-1/PD-L1 Inhibitory Molecules [230]. The PD1/PD-L1 system can also be considered a tumor counterattack strategy. The programmed death-1 (PD-1) molecule is a member of the CD28 family. The ligands for PD-1 (PDLs) are PD-L1 (B7-H1) and PD-L2 (B7-DC). Upon signal transduction with these proteins the $\mathrm{T}$ cells become triggered for cell death via apoptosis. PD-L1 has been detected on human lung cancers. Dong et al. [231] showed 95\% of the lung cancers (20 of 21 , including adenocarcinomas, squamous and small cell) were positive for B7-H1(PDL1). Iwai and colleagues [232] also showed a similar type of mechanism. Brown et al. [233] also showed 6 of 6 adenocarcinomas and 8 of 8 squamous cancers were strongly positive for PD-L1(B7-H1). When in situ lung cancers expressed more $\mathrm{B} 7-\mathrm{H} 1$, there were fewer $\mathrm{T}$ cells present than in the B7-H1 negative cancers [234]. Perrot et al. [235] 
also showed that the myeloid dendritic cells that infiltrated NSCLC were blocked in an immature state and were B7-H1+.

Besides the B7-H1 and B7-DC molecules, a couple of other family members with similar biological functions, namely $\mathrm{B} 7-\mathrm{H} 3$ and $\mathrm{B} 7-\mathrm{H} 4$, are expressed on various NSCL cell lines. These markers are found within in situ squamous and large cell carcinomas [236, 237]. Roughly half of lung cancers expressed at least one of these markers.

A variety of antibodies from various companies, BristolMyers Squibb, Merck, GlaxoSmithKline, and Cure Tech, are targeting these receptors/ligands, which also can inhibit $\mathrm{T}$ cell and NK cell responses. One interesting fact is that these antibodies do not have as much toxicity as the anti-CTLA4 antibodies seem to possess [124]. Thus, this antibody will probably be the best way to target the immunosupressor cells.

8.4. The Previous Use of an ONTAK Immunotoxin Which Depletes Treg [238] via the High-Affinity IL-2 Receptor (See Section 5.3.2(a)) Is Another Way to Target This Same Receptor. Daclizumab [239] targets the high-affinity interleukin-2 receptor- $\alpha$ on Treg cells. By eliminating Treg cells, a more sustained antitumor immune response can also be maintained. This therapy is currently being tried in melanoma patients at the University of Chicago and in glioma patients at Duke University. Here the idea is to eliminate the Treg before they inhibit the optimal anti-cancer immune response. Since LC has high concentrations of Treg, this could prove to be very good at improving clinical results.

\section{Summary}

Education is often considered a painful process, and that is certainly true in the case of lung cancer. Each new lesson requires expensive clinical trials to learn this vital information. Each cancer has its own unique set of tricks to avoid clinical therapies. Lung cancers use a variety of defensive strategies to escape chemo- and radiation therapies also can serve double duty by resisting the immune system. Immunologists are beginning to design rational therapies to counteract these defensive strategies. It will still take work to develop effective therapies against this killer cancer. Most likely, no single immunotherapy will work as a stand-alone therapy and it will have to be combined with other therapies to achieve a cure. Progress with immunotherapy is slowly being made against other cancers previously considered terminal cancers, that is, melanoma, glioma, and castrateresistant prostate cancer. The lessons learned in those clinical trials can certainly be applied towards lung cancer.

\section{Acknowledgment}

The authors thank Susan Holsclaw for the artwork done for this paper.

\section{References}

[1] R. M. Prins, H. Soto, V. Konkankit et al., "Gene expression profile correlates with T-cell infiltration and relative survival in glioblastoma patients vaccinated with dendritic cell immunotherapy," Clinical Cancer Research, vol. 17, no. 6, pp. 1603-1615, 2011.

[2] J. L. Gulley and C. G. Drake, "Immunotherapy for prostate cancer: recent advances, lessons learned, and areas for further research," Clinical Cancer Research, vol. 17, no. 12, pp. 38843891, 2011.

[3] S. S. Hecht, "Tobacco smoke carcinogens and lung cancer," Journal of the National Cancer Institute, vol. 91, no. 14, pp. 1194-1210, 1999.

[4] J. G. Paez, P. A. Jänne, J. C. Lee et al., "EGFR mutations in lung, cancer: correlation with clinical response to gefitinib therapy," Science, vol. 304, no. 5676, pp. 1497-1500, 2004.

[5] T. Kosaka, Y. Yatabe, H. Endoh, H. Kuwano, T. Takahashi, and T. Mitsudomi, "Mutations of the epidermal growth factor receptor gene in lung cancer: biological and clinical implications," Cancer Research, vol. 64, no. 24, pp. 89198923, 2004

[6] D. W. S. Wong, E. L. H. Leung, K. K. T. So et al., "The EML4ALK fusion gene is involved in various histologic types of lung cancers from nonsmokers with wild-type EGFR and KRAS," Cancer, vol. 115, no. 8, pp. 1723-1733, 2009.

[7] K. Inamura, K. Takeuchi, Y. Togashi et al., "EML4-ALK lung cancers are characterized by rare other mutations, a TTF-1 cell lineage, an acinar histology, and young onset," Modern Pathology, vol. 22, no. 4, pp. 508-515, 2009.

[8] S. Sun, J. H. Schiller, and A. F. Gazdar, "Lung cancer in never smokers-a different disease," Nature Reviews Cancer, vol. 7, no. 10, pp. 778-790, 2007.

[9] E. Ruffini, S. Asioli, P. L. Filosso et al., "Clinical Significance of Tumor-Infiltrating Lymphocytes in Lung Neoplasms," Annals of Thoracic Surgery, vol. 87, no. 2, pp. 365-372, 2009.

[10] S. Bao, Q. Wu, R. E. McLendon et al., "Glioma stem cells promote radioresistance by preferential activation of the DNA damage response," Nature, vol. 444, no. 7120, pp. 756760, 2006.

[11] G. Liu, X. Yuan, Z. Zeng et al., "Analysis of gene expression and chemoresistance of $\mathrm{CD} 133^{+}$cancer stem cells in glioblastoma," Molecular Cancer, vol. 5, article 67, 2006.

[12] G. Bertolini, L. Roz, P. Perego et al., "Highly tumorigenic lung cancer $\mathrm{CD} 133^{+}$cells display stem-like features and are spared by cisplatin treatment," Proceedings of the National Academy of Sciences of the United States of America, vol. 106, no. 38, pp. 16281-16286, 2009.

[13] E. M. Hurt and W. L. Farrar, "Purification and characterization of cancer stem cells," in Cancer Stem Cells, pp. 1-14, Cambridge University Press, Cambridge, Mass, USA, 2009.

[14] C. Lagadec, E. Vlashi, L. D. Donna et al., "Survival and self-renewing capacity of breast cancer initiating cells during fractionated radiation treatment," Breast Cancer Research, vol. 12, no. 1, article R13, 2010.

[15] G. Ambrosini, C. Adida, and D. C. Altieri, "A novel antiapoptosis gene, survivin, expressed in cancer and lymphoma," Nature Medicine, vol. 3, no. 8, pp. 917-921, 1997.

[16] R. M. Apolinario, P. van der Valk, J. S. De Jong et al., "Prognostic value of the expression of p53, bcl-2, and box oncoproteins, and neovascularization in patients with radically resected non-small-cell lung cancer," Journal of Clinical Oncology, vol. 15, no. 6, pp. 2456-2466, 1997.

[17] F. Pezzella, H. Turley, I. Kuzu et al., "bcl-2 Protein in nonsmall-cell lung carcinoma," The New England Journal of Medicine, vol. 329, no. 10, pp. 690-694, 1993.

[18] H. Hariu, Y. Hirohashi, T. Torigoe et al., "Aberrant expression and potency as a cancer immunotherapy target of inhibitor 
of apoptosis protein family, Livin/ML-IAP in lung cancer," Clinical Cancer Research, vol. 11, no. 3, pp. 1000-1009, 2005.

[19] E. Brambilla, A. Negoescu, S. Gazzeri et al., "Apoptosisrelated factors $\mathrm{p} 53, \mathrm{Bcl} 2$, and Bax in neuroendocrine lung tumors," American Journal of Pathology, vol. 149, no. 6, pp. 1941-1952, 1996.

[20] R. A. Olie, A. P. Simões-Wüst, B. Baumann et al., "A novel antisense oligonucleotide targeting survivin expression induces apoptosis and sensitizes lung cancer cells to chemotherapy," Cancer Research, vol. 60, no. 11, pp. 28052809, 2000.

[21] M. Monzó, R. Rosell, E. Felip et al., "A novel anti-apoptosis gene: re-expression of survivin messenger RNA as a prognosis marker in non-small-cell lung cancers," Journal of Clinical Oncology, vol. 17, no. 7, pp. 2100-2104, 1999.

[22] A. Fine, Y. Janssen-Heininger, R. P. Soultanakis, S. G. Swisher, and B. D. Uhal, "Apoptosis in lung pathophysiology," American Journal of Physiology, vol. 279, no. 3, pp. L423L427, 2000.

[23] B. Joseph, R. Lewensohn, and B. Zhivotovsky, "Role of apoptosis in the response of lung carcinomas to anti-cancer treatment," Annals of the New York Academy of Sciences, vol. 926, no. 1, pp. 204-216, 2000.

[24] K. Krysan, H. Dalwadi, S. Sharma, M. Põld, and S. M. Dubinett, "Cyclooxygenase 2-dependent expression of survivin is critical for apoptosis resistance in non-small cell lung cancer," Cancer Research, vol. 64, no. 18, pp. 6359-6362, 2004.

[25] H. Sheng, J. Shao, J. D. Morrow, R. D. Beauchamp, and R. N. DuBois, "Modulation of apoptosis and Bcl-2 expression by prostaglandin E2 in human colon cancer cells," Cancer Research, vol. 58, no. 2, pp. 362-366, 1998.

[26] B. Joseph, J. Ekedahl, F. Sirzen, R. Lewensohn, and B. Zhivotovsky, "Differences in expression of pro-caspases in small cell and non-small cell lung carcinoma," Biochemical and Biophysical Research Communications, vol. 262, no. 2, pp. 381-387, 1999.

[27] N. Shivapurkar, J. Reddy, H. Matta et al., "Loss of expression of death-inducing signaling complex (DISC) components in lung cancer cell lines and the influence of MYC amplification," Oncogene, vol. 21, no. 55, pp. 8510-8514, 2002.

[28] N. Shivapurkar, S. Toyooka, M. T. Eby et al., "Differential inactivation of caspase-8 in lung cancers," Cancer Biology and Therapy, vol. 1, no. 1, pp. 65-69, 2002.

[29] E. Brambilla, S. Gazzeri, S. Lantuejoul et al., "p53 mutant immunophenotype and deregulation of p53 transcription pathway (Bcl2, Bax, and Waf1) in precursor bronchial lesions of lung cancer," Clinical Cancer Research, vol. 4, no. 7, pp. 1609-1618, 1998.

[30] S. Zöchbauer-Müller, A. F. Gazdar, and J. D. Minna, "Molecular pathogenesis of lung cancer," Annual Review of Physiology, vol. 64, pp. 681-708, 2002.

[31] G. Pelosi, F. Pasini, C. O. Stenholm et al., "p63 immunoreactivity in lung cancer: yet another player in the development of squamous cell carcinomas?" Journal of Pathology, vol. 198, no. 1, pp. 100-109, 2002.

[32] M. B. Schabath, X. Wu, Q. Wei, G. Li, J. Gu, and M. R. Spitz, "Combined effects of the p53 and p73 polymorphisms on lung cancer risk," Cancer Epidemiology Biomarkers and Prevention, vol. 15, no. 1, pp. 158-161, 2006.

[33] R. N. Barker, L. P. Erwig, W. P. Pearce, A. Devine, and A. J. Rees, "Differential effects of necrotic or apoptotic cell uptake on antigen presentation by macrophages," Pathobiology, vol. 67, no. 5-6, pp. 302-305, 2000.
[34] R. E. Voll, M. Herrmann, E. A. Roth, C. Stach, J. R. Kalden, and I. Girkontaite, "Immunosuppressive effects of apoptotic cells," Nature, vol. 390, no. 6658, pp. 350-351, 1997.

[35] R. M. Steinman, S. Turley, I. Mellman, and K. Inaba, "The induction of tolerance by dendritic cells that have captured apoptotic cells," Journal of Experimental Medicine, vol. 191, no. 3, pp. 411-416, 2000.

[36] B. Sauter, M. L. Albert, L. Francisco, M. Larsson, S. Somersan, and N. Bhardwaj, "Consequences of cell death: exposure to necrotic tumor cells, but not primary tissue cells or apoptotic cells, induces the maturation of immunostimulatory dendritic cells," Journal of Experimental Medicine, vol. 191, no. 3, pp. 423-433, 2000.

[37] V. A. Fadok, D. L. Bratton, A. Konowal, P. W. Freed, J. Y. Westcott, and P. M. Henson, "Macrophages that have ingested apoptotic cells in vitro inhibit proinflammatory cytokine production through autocrine/paracrine mechanisms involving TGF- $\beta$, PGE2, and PAF," Journal of Clinical Investigation, vol. 101, no. 4, pp. 890-898, 1998.

[38] C. Fonseca and G. Dranoff, "Capitalizing on the immunogenicity of dying tumor cells," Clinical Cancer Research, vol. 14, no. 6, pp. 1603-1608, 2008.

[39] E. Ullrich, M. Bonmort, G. Mignot, G. Kroemer, and L. Zitvogel, "Tumor stress, cell death and the ensuing immune response," Cell Death and Differentiation, vol. 15, no. 1, pp. 21-28, 2008.

[40] O. Kepp, L. Galluzzi, I. Martins et al., "Molecular determinants of immunogenic cell death elicited by anticancer chemotherapy," Cancer and Metastasis Reviews, vol. 30, no. 1, pp. 61-69, 2011.

[41] L. C. Young, B. G. Campling, S. P. C. Cole, R. G. Deeley, and J. H. Gerlach, "Multidrug resistance proteins MRP3, MRP1, and MRP2 in lung cancer: correlation of protein levels with drug response and messenger RNA levels," Clinical Cancer Research, vol. 7, no. 6, pp. 1798-1804, 2001.

[42] L. C. Young, B. G. Campling, T. Voskoglou-Nomikos, S. P. C. Cole, R. G. Deeley, and J. H. Gerlach, "Expression of multidrug resistance protein-related genes in lung cancer: correlation with drug response," Clinical Cancer Research, vol. 5, no. 3, pp. 673-680, 1999.

[43] C. M. Mahaffey, N. C. Mahaffey, W. Holland et al., "Aberrant regulation of the MRP3 gene in non-small cell lung carcinoma," Journal of Thoracic Oncology, vol. 7, no. 1, pp. 34-39, 2012.

[44] N. Triller, P. Korošec, I. Kern, M. Košnik, and A. Debeljak, "Multidrug resistance in small cell lung cancer: expression of P-glycoprotein, multidrug resistance protein 1 and lung resistance protein in chemo-naive patients and in relapsed disease," Lung Cancer, vol. 54, no. 2, pp. 235-240, 2006.

[45] J. P. Sullivan, M. Spinola, M. Dodge et al., "Aldehyde dehydrogenase activity selects for lung adenocarcinoma stem cells dependent on notch signaling," Cancer Research, vol. 70, no. 23, pp. 9937-9948, 2010.

[46] C. E. Griguer, C. R. Oliva, E. Gobin et al., "CD133 is a marker of bioenergetic stress in human glioma," PLoS ONE, vol. 3, no. 11, article e3655, 2008.

[47] J. M. Angelastro and M. W. Lamé, “Overexpression of CD133 promotes drug resistance in C6 glioma cells," Molecular Cancer Research, vol. 8, no. 8, pp. 1105-1115, 2010.

[48] C. Hirschmann-Jax, A. E. Foster, G. G. Wulf et al., "A distinct "side population" of cells with high drug efflux capacity in human tumor cells," Proceedings of the National Academy of Sciences of the United States of America, vol. 101, no. 39, pp. 14228-14233, 2004. 
[49] T. L. McLemore, W. C. Hubbard, C. L. Litterst et al., "Profiles of prostaglandin biosynthesis in normal lung and tumor tissue from lung cancer patients," Cancer Research, vol. 48, no. 11, pp. 3140-3147, 1988.

[50] C. D. Funk, "Prostaglandins and leukotrienes: advances in eicosanoid biology," Science, vol. 294, no. 5548, pp. 18711875, 2001.

[51] Y. Cao and S. M. Prescott, "Many actions of cyclooxygenase2 in cellular dynamics and in cancer," Journal of Cellular Physiology, vol. 190, no. 3, pp. 279-286, 2002.

[52] H. Wolff, K. Saukkonen, S. Anttila, A. Karjalainen, H. Vainio, and A. Ristimäki, "Expression of cyclooxygenase-2 in human lung carcinoma," Cancer Research, vol. 58, no. 22, pp. 49975001, 1998.

[53] D. M. Schreinemachers and R. B. Everson, "Aspirin use and lung, colon, and breast cancer incidence in a prospective study," Epidemiology, vol. 5, no. 2, pp. 138-146, 1994.

[54] A. N. Hata and R. M. Breyer, "Pharmacology and signaling of prostaglandin receptors: multiple roles in inflammation and immune modulation," Pharmacology and Therapeutics, vol. 103, no. 2, pp. 147-166, 2004.

[55] L. Yang, N. Yamagata, R. Yadav et al., "Cancer-associated immunodefidency and dendritic cell abnormalities mediated by the prostaglandin EP2 receptor," Journal of Clinical Investigation, vol. 111, no. 5, pp. 727-735, 2003.

[56] J. I. Kim, V. Lakshmikanthan, N. Frilot, and Y. Daaka, "Prostaglandin E2 promotes lung cancer cell migration via EP4- $\beta$ /Arrestin1-c-Src signalsome," Molecular Cancer Research, vol. 8, no. 4, pp. 569-577, 2010.

[57] M. Dohadwala, R. K. Batra, J. Luo et al., "Autocrine/paracrine prostaglandin E2 production by non-small cell lung cancer cells regulates matrix metalloproteinase-2 and CD44 in cyclooxygenase-2-dependent invasion," The Journal of Biological Chemistry, vol. 277, no. 52, pp. 50828-50833, 2002.

[58] M. Dohadwala, J. Luo, L. Zhu et al., "Non-small cell lung cancer cyclooxygenase-2-dependent invasion is mediated by CD44," The Journal of Biological Chemistry, vol. 276, no. 24, pp. 20809-20812, 2001.

[59] K. Krysan, K. L. Reckamp, H. Dalwadi et al., "Prostaglandin E2 activates mitogen-activated protein kinase/Erk pathway signaling and cell proliferation in non-small cell lung cancer cells in an epidermal growth factor receptor-independent manner," Cancer Research, vol. 65, no. 14, pp. 6275-6281, 2005.

[60] J. Watson, "The influence of intracellular levels of cyclic nucleotides on cell proliferation and the induction of antibody synthesis," Journal of Experimental Medicine, vol. 141, no. 1, pp. 97-111, 1975.

[61] G. M. Kammer, "The adenylate cyclase-cAMP-protein kinase A pathway and regulation of the immune response," Immunology Today, vol. 9, no. 7-8, pp. 222-229, 1988.

[62] M. Huang, S. Sharma, J. T. Mao, and S. M. Dubinett, "Non-small cell lung cancer-derived soluble mediators and prostaglandin E2 enhance peripheral blood lymphocyte IL-10 transcription and protein production," Journal of Immunology, vol. 157, no. 12, pp. 5512-5520, 1996.

[63] M. Huang, M. Stolina, S. Sharma et al., "Non-small cell lung cancer cyclooxygenase-2-dependent regulation of cytokine balance in lymphocytes and macrophages: up-regulation of interleukin 10 and down-regulation of interleukin 12 production," Cancer Research, vol. 58, no. 6, pp. 1208-1216, 1998.

[64] S. Sharma, M. Stolina, Y. Lin et al., "T cell-derived IL-10 promotes lung cancer growth by suppressing both $\mathrm{T}$ cell and
APC function," Journal of Immunology, vol. 163, no. 9, pp. 5020-5028, 1999.

[65] D. Miotto, N. Lo Cascio, M. Stendardo et al., "CD8 ${ }^{+}$T cells expressing IL-10 are associated with a favourable prognosis in lung cancer," Lung Cancer, vol. 69, no. 3, pp. 355-360, 2010.

[66] S. Mocellin, F. M. Marincola, and H. A. Young, "Interleukin10 and the immune response against cancer: a counterpoint," Journal of Leukocyte Biology, vol. 78, no. 5, pp. 1043-1051, 2005.

[67] M. V. Lopez, S. K. Adris, A. I. Bravo, Y. Chernajovsky, and O. L. Podhajcer, "IL-12 and IL-10 expression synergize to induce the immune-mediated eradication of established colon and mammary tumors and lung metastasis," Journal of Immunology, vol. 175, no. 9, pp. 5885-5894, 2005.

[68] M. Huang, J. Wang, P. Lee et al., "Human non-small cell lung cancer cells express a type 2 cytokine pattern," Cancer Research, vol. 55, no. 17, pp. 3847-3853, 1995.

[69] S. R. Pine, L. E. Mechanic, L. Enewold et al., "Increased levels of circulating interleukin 6 , interleukin 8 , c-reactive protein, and risk of lung cancer," Journal of the National Cancer Institute, vol. 103, no. 14, pp. 1112-1122, 2011.

[70] E. Wójcik, J. Jakubowicz, P. Skotnicki, B. Sas-Korczyńska, and J. K. Kulpa, "IL-6 and VEGF in small cell lung cancer patients," Anticancer Research, vol. 30, no. 5, pp. 1773-1778, 2010.

[71] P. Salven, T. Ruotsalainen, K. Mattson, and H. Joensuu, "High pre-treatment serum level of vascular endothelial growth factor (VEGF) is associated with poor outcome in small-cell lung cancer," International Journal of Cancer, vol. 79, no. 2, pp. 144-146, 1998.

[72] P. Salven, H. Mäenpää, A. Orpana, K. Alitalo, and H. Joensuu, "Serum vascular endothelial growth factor is often elevated in disseminated cancer," Clinical Cancer Research, vol. 3, no. 5, pp. 647-651, 1997.

[73] T. Kajita, Y. Ohta, K. Kimura et al., "The expression of vascular endothelial growth factor $\mathrm{C}$ and its receptors in nonsmall cell lung cancer," British Journal of Cancer, vol. 85, no. 2, pp. 255-260, 2001.

[74] P. Delmotte, B. Martin, M. Paesmans et al., "The role of vascular endothelial growth factor in the survival of patients with lung cancer: a systematic literature review and metaanalysis," Revue des Maladies Respiratoires, vol. 19, no. 5, pp. 577-584, 2002.

[75] M. Volm, R. Koomägi, and J. Mattern, "Prognostic value of vascular endothelial growth factor and its receptor Flt-1 in squamous cell lung cancer," International Journal of Cancer, vol. 74, no. 1, pp. 64-68, 1997.

[76] S. Tanno, Y. Ohsaki, K. Nakanishi, E. Toyoshima, and K. Kikuchi, "Human small cell lung cancer cells express functional VEGF receptors, VEGFR-2 and VEGFR-3," Lung Cancer, vol. 46, no. 1, pp. 11-19, 2004.

[77] D. I. Gabrilovich, H. L. Chen, K. R. Girgis et al., "Production of vascular endothelial growth factor by human tumors inhibits the functional maturation of dendritic cells," Nature Medicine, vol. 2, no. 10, pp. 1096-1103, 1996.

[78] S. J. Lee, S. Y. Lee, H. S. Jeon et al., "Vascular endothelial growth factor gene polymorphisms and risk of primary lung cancer," Cancer Epidemiology Biomarkers and Prevention, vol. 14, no. 3, pp. 571-575, 2005.

[79] B. Bierie and H. L. Moses, "Tumour microenvironmentTGF $\beta$ : the molecular Jekyll and Hyde of cancer," Nature Reviews Cancer, vol. 6, no. 7, pp. 506-520, 2006.

[80] G. J. Prud'homme, "Pathobiology of transforming growth factor $\beta$ in cancer, fibrosis and immunologic disease, and 
therapeutic considerations," Laboratory Investigation, vol. 87, no. 11, pp. 1077-1091, 2007.

[81] Y. Hasegawa, S. Takanashi, Y. Kanehira et al., "Transforming growth factor-betal level correlates with angiogenesis, tumor progression, and prognosis in patients with nonsmall cell lung carcinoma," Cancer, vol. 91, no. 5, pp. 964-971, 2001.

[82] S. B. Jakowlew, A. Mathias, P. Chung, and T. W. Moody, "Expression of transforming growth factor $\beta$ ligand and receptor messenger RNAs in lung cancer cell lines," Cell Growth and Differentiation, vol. 6, no. 4, pp. 465-476, 1995.

[83] S. Hougaard, P. Nørgaard, N. Abrahamsen, H. L. Moses, M. Spang-Thomsen, and H. S. Poulsen, "Inactivation of the transforming growth factor $\beta$ type II receptor in human small cell lung cancer cell lines," British Journal of Cancer, vol. 79, no. 7-8, pp. 1005-1011, 1999.

[84] L. Damstrup, K. Rygaard, M. Spang-Thomsen, and H. S. Poulsen, "Expression of transforming growth factor $\beta$ (TGF $\beta$ ) receptors and expression of TGF $\beta 1$, TGF $\beta 2$ and TGF $\beta 3$ in human small cell lung cancer cell lines," British Journal of Cancer, vol. 67, no. 5, pp. 1015-1021, 1993.

[85] T. K. Kim, E. K. Mo, C. G. Yoo et al., "Alteration of cell growth and morphology by overexpression of transforming growth factor $\beta$ type II receptor in human lung adenocarcinoma cells," Lung Cancer, vol. 31, no. 2-3, pp. 181-191, 2001.

[86] R. R. de Jonge, L. Garrigue-Antar, V. F. Vellucci, and M. Reiss, "Frequent inactivation of the transforming growth factor $\beta$ type ii receptor in small-cell lung carcinoma cells," Oncology Research, vol. 9, no. 2, pp. 89-98, 1997.

[87] S. B. Jakowlew, A. Mathias, P. Chung, and T. W. Moody, "Expression of transforming growth factor $\beta$ ligand and receptor messenger RNAs in lung cancer cell lines," Cell Growth and Differentiation, vol. 6, no. 4, pp. 465-476, 1995.

[88] J. R. Fischer, H. Darjes, H. Lahm, M. Schindel, P. Drings, and P. H. Krammer, "Constitutive secretion of bioactive transforming growth factor $\beta 1$ by small cell lung cancer cell lines," European Journal of Cancer Part A, vol. 30, no. 14, pp. 2125-2129, 1994.

[89] J. J. Letterio and A. B. Roberts, "Regulation of immune responses by TGF- $\beta$," Annual Review of Immunology, vol. 16, pp. 137-161, 1998.

[90] H. G. Kang, M. H. Chae, J. M. Park et al., "Polymorphisms in TGF- $\beta 1$ gene and the risk of lung cancer," Lung Cancer, vol. 52, no. 1, pp. 1-7, 2006.

[91] S. Sharma, S. C. Yang, L. Zhu et al., "Tumor cyclooxygenase2/prostaglandin E2-dependent promotion of FOXP3 expression and $\mathrm{CD}^{+} \mathrm{CD} 25^{+} \mathrm{T}$ regulatory cell activities in lung cancer," Cancer Research, vol. 65, no. 12, pp. 5211-5220, 2005.

[92] P. Sinha, V. K. Clements, A. M. Fulton, and S. OstrandRosenberg, "Prostaglandin E2 promotes tumor progression by inducing myeloid-derived suppressor cells," Cancer Research, vol. 67, no. 9, pp. 4507-4513, 2007.

[93] A. Hamaï, P. Pignon, I. Raimbaud et al., "Human TH17 immune cells specific for the tumor antigen MAGE-A3 convert to IFN- $\gamma$ secreting cells as they differentiate into effector T cells in vivo," Cancer Research, vol. 72, no. 5, pp. $1-5,2012$.

[94] S. Z. Ben-Sasson, J. Hu-Li, J. Quiel et al., "IL-1 acts directly on CD4 T cells to enhance their antigen-driven expansion and differentiation," Proceedings of the National Academy of Sciences of the United States of America, vol. 106, no. 17, pp. 7119-7124, 2009.

[95] W. W. Lee, S. W. Kang, J. Choi et al., "Regulating human Th17 cells via differential expression of IL-1 receptor," Blood, vol. 115 , no. 3, pp. 530-540, 2010.
[96] K. Boniface, K. S. Bak-Jensen, Y. Li et al., "Prostaglandin E2 regulates Th17 cell differentiation and function through cyclic AMP and EP2/EP4 receptor signaling," Journal of Experimental Medicine, vol. 206, no. 3, pp. 535-548, 2009.

[97] C. Chizzolini, R. Chicheportiche, M. Alvarez et al., "Prostaglandin E2 synergistically with interleukin-23 favors human Th17 expansion," Blood, vol. 112, no. 9, pp. 36963703, 2008.

[98] N. Martin-Orozco, P. Muranski, Y. Chung et al., "T helper 17 cells promote cytotoxic T cell activation in tumor immunity," Immunity, vol. 31, no. 5, pp. 787-798, 2009.

[99] Y. Ji and W. Zhang, "Th17 cells: positive or negative role in tumor?" Cancer Immunology, Immunotherapy, vol. 59, no. 7, pp. 979-987, 2010.

[100] P. P. Ho and L. Steinman, "The aryl hydrocarbon receptor: a regulator of Th17 and Treg cell development in disease," Cell Research, vol. 18, no. 6, pp. 605-608, 2008.

[101] C. A. Martey, C. J. Baglole, T. A. Gasiewicz, P. J. Sime, and R. P. Phipps, "The aryl hydrocarbon receptor is a regulator of cigarette smoke induction of the cyclooxygenase and prostaglandin pathways in human lung fibroblasts," American Journal of Physiology, vol. 289, no. 3, pp. L391L399, 2005.

[102] J. T. Chang, H. Chang, P. H. Chen, S. L. Lin, and P. Lin, "Requirement of aryl hydrocarbon receptor overexpression for CYP1B1 up-regulation and cell growth in human lung adenocarcinomas," Clinical Cancer Research, vol. 13, no. 1, pp. 38-45, 2007.

[103] C. J. Baglole, S. B. Maggirwar, T. A. Gasiewicz, T. H. Thatcher, R. P. Phipps, and P. J. Sime, "The aryl hydrocarbon receptor attenuates tobacco smoke-induced cyclooxygenase2 and prostaglandin production in lung fibroblasts through regulation of the NF- $\kappa \mathrm{B}$ family member RelB," The Journal of Biological Chemistry, vol. 283, no. 43, pp. 28944-28957, 2008.

[104] N. T. Nguyen, A. Kimura, T. Nakahama et al., "Aryl hydrocarbon receptor negatively regulates dendritic cell immunogenicity via a kynurenine-dependent mechanism," Proceedings of the National Academy of Sciences of the United States of America, vol. 107, no. 46, pp. 19961-19966, 2010.

[105] K. Mahnke, K. Schönfeld, S. Fondel et al., "Depletion of $\mathrm{CD} 4^{+} \mathrm{CD} 25^{+}$human regulatory $\mathrm{T}$ cells in vivo: kinetics of Treg depletion and alterations in immune functions in vivo and in vitro," International Journal of Cancer, vol. 120, no. 12, pp. 2723-2733, 2007.

[106] S. G. Zheng, J. H. Wang, J. D. Gray, H. Soucier, and D. A. Horwitz, "Natural and induced $\mathrm{CD} 4{ }^{+} \mathrm{CD} 25^{+}$cells educate $\mathrm{CD} 4{ }^{+} \mathrm{CD} 25^{-}$cells to develop suppressive activity: the role of IL-2, TGF- $\beta$, and IL-10," Journal of Immunology, vol. 172, no. 9, pp. 5213-5221, 2004.

[107] R. P. Petersen, M. J. Campa, J. Sperlazza et al., "Tumor infiltrating $\mathrm{FOXP}^{+}$regulatory T-cells are associated with recurrence in pathologic stage I NSCLC patients," Cancer, vol. 107, no. 12, pp. 2866-2872, 2006.

[108] C. A. Granville, R. M. Memmott, and A. Balogh, "A central role for Foxp3+ regulatory $\mathrm{T}$ cells in K-Ras-driven lung tumorigenesis," Plos ONE, vol. 4, no. 3, article e5061, 2009.

[109] E. Y. Woo, H. Yeh, C. S. Chu et al., "Cutting edge: regulatory $\mathrm{T}$ cells from lung cancer patients directly inhibit autologous T cell proliferation," Journal of Immunology, vol. 168, no. 9, pp. 4272-4276, 2002.

[110] E. Y. Woo, C. S. Chu, T. J. Goletz et al., "Regulatory $\mathrm{CD} 4{ }^{+} \mathrm{CD} 25^{+} \mathrm{T}$ cells in tumors from patients with early-stage non-small cell lung cancer and late-stage ovarian cancer," Cancer Research, vol. 61, no. 12, pp. 4766-4772, 2001. 
[111] M. D. Sharma, D. Y. Hou, Y. Liu et al., "Indoleamine 2,3dioxygenase controls conversion of Foxp3+ Tregs to TH17like cells in tumor-draining lymph nodes," Blood, vol. 113, no. 24, pp. 6102-6111, 2009.

[112] S. Löb, A. Königsrainer, D. Zieker et al., "IDO1 and IDO2 are expressed in human tumors: levo- but not dextro-1methyl tryptophan inhibits tryptophan catabolism," Cancer Immunology, Immunotherapy, vol. 58, no. 1, pp. 153-157, 2009.

[113] C. Uyttenhove, L. Pilotte, I. Théate et al., "Evidence for a tumoral immune resistance mechanism based on tryptophan degradation by indoleamine 2,3-dioxygenase," Nature Medicine, vol. 9, no. 10, pp. 1269-1274, 2003.

[114] G. C. Prendergast, "Immune escape as a fundamental trait of cancer: focus on IDO," Oncogene, vol. 27, no. 28, pp. 3889 3900, 2008.

[115] J. V. Karanikas, M. Zamanakou, T. Kerenidi et al., "Indoleamine 2,3-dioxygenase (IDO) expression in lung cancer," Cancer Biology and Therapy, vol. 6, no. 8, pp. 12581262, 2007.

[116] M. Friberg, R. Jennings, M. Alsarraj et al., "Indoleamine 2,3-dioxygenase contributes to tumor cell evasion of T cellmediated rejection," International Journal of Cancer, vol. 101, no. 2, pp. 151-155, 2002.

[117] S. Astigiano, B. Morandi, R. Costa et al., "Eosinophil granulocytes account for indoleamine 2,3-dioxygenase-mediated immune escape in human non-small cell lung cancer," Neoplasia, vol. 7, no. 4, pp. 390-396, 2005.

[118] D. R. Leach, M. F. Krummel, and J. P. Allison, "Enhancement of antitumor immunity by CTLA-4 blockade," Science, vol. 271, no. 5256, pp. 1734-1736, 1996.

[119] A. J. Montero, C. M. Diaz-Montero, C. E. Kyriakopoulos et al., "Myeloid-derived suppressor cells in cancer patients: a clinical perspective," Journal of Immunotherapy, vol. 35, no. 2, pp. 107-115, 2012.

[120] D. I. Gabrilovich and S. Nagaraj, "Myeloid-derived suppressor cells as regulators of the immune system," Nature Reviews Immunology, vol. 9, no. 3, pp. 162-174, 2009.

[121] S. Ostrand-Rosenberg and P. Sinha, "Myeloid-derived suppressor cells: linking inflammation and cancer," Journal of Immunology, vol. 182, no. 8, pp. 4499-4506, 2009.

[122] M. R. Jadus and R. Parkman, "The selective growth of murine newborn-derived suppressor cells and their probable mode of action," Journal of Immunology, vol. 136, no. 3, pp. 783792, 1986.

[123] P. C. Rodriguez, C. P. Hernandez, D. Quiceno et al., "Arginase I in myeloid suppressor cells is induced by COX-2 in lung carcinoma," Journal of Experimental Medicine, vol. 202, no. 7, pp. 931-939, 2005.

[124] D. Pardoll and C. Drake, "Immunotherapy earns its spot in the ranks of cancer therapy," Journal of Experimental Medicine, vol. 209, no. 2, pp. 201-209, 2012.

[125] J. E. Talmadge, K. C. Hood, L. C. Zobel, L. R. Shafer, M. Coles, and B. Toth, "Chemoprevention by cyclooxygenase2 inhibition reduces immature myeloid suppressor cell expansion," International Immunopharmacology, vol. 7, no. 2, pp. 140-151, 2007.

[126] S. Brandau, S. Trellakis, K. Bruderek et al., "Myeloid-derived suppressor cells in the peripheral blood of cancer patients contain a subset of immature neutrophils with impaired migratory properties," Journal of Leukocyte Biology, vol. 89, no. 2, pp. 311-317, 2011.

[127] Y. Liu, J. A. Van Ginderachter, L. Brys, P. De Baetselier, G. Raes, and A. B. Geldhof, "Nitric oxide-independent
CTL suppression during tumor progression: association with arginase-producing (M2) myeloid cells," Journal of Immunology, vol. 170, no. 10, pp. 5064-5074, 2003.

[128] I. M. Corraliza, G. Soler, K. Eichmann, and M. Modolell, "Arginase induction by suppressors of nitric oxide synthesis (IL-4, IL-10 and PGE2) in murine bone-marrow-derived macrophages," Biochemical and Biophysical Research Communications, vol. 206, no. 2, pp. 667-673, 1995.

[129] A. C. Ochoa, A. H. Zea, C. Hernandez, and P. C. Rodriguez, "Arginase, prostaglandins, and myeloid-derived suppressor cells in renal cell carcinoma," Clinical Cancer Research, vol. 13, no. 2, pp. 721s-726s, 2007.

[130] M. Modolell, I. M. Corraliza, F. Link, G. Soler, and K. Eichmann, "Reciprocal regulation of the nitric oxide synthase-arginase balance in mouse bone marrow-derived macrophages by TH1 and TH2 cytokines," European Journal of Immunology, vol. 25, no. 4, pp. 1101-1104, 1995.

[131] N. Umemura, M. Saio, T. Suwa et al., "Tumor-infiltrating myeloid-derived suppressor cells are pleiotropic-inflamed monocytes/macrophages that bear M1- and M2-type characteristics," Journal of Leukocyte Biology, vol. 83, no. 5, pp. 1136-1144, 2008.

[132] K. L. Choi, T. Maier, J. H. Holda, and H. N. Claman, "Suppression of cytotoxic T-cell generation by natural suppressor cells from mice with GVHD is partially reserved by indomethacin," Cellular Immunology, vol. 112, no. 2, pp. 271-278, 1988.

[133] T. Baba, T. Hanagiri, Y. Ichiki et al., "Lack and restoration of sensitivity of lung cancer cells to cellular attack with special reference to expression of human leukocyte antigen class I and/or major histocompatibility complex class I chain related molecules A/B," Cancer Science, vol. 98, no. 11, pp. 17951802, 2007.

[134] A. Doyle, W. J. Martin, K. Funa et al., "Markedly decreased expression of class I histocompatibility antigens, protein, and mRNA in human small-cell lung cancer," Journal of Experimental Medicine, vol. 161, no. 5, pp. 1135-1151, 1985.

[135] D. P. Singal, M. Ye, and X. Qiu, "Molecular basis for lack of expression of HLA class I antigens in human small-cell lung carcinoma cell lines," International Journal of Cancer, vol. 68, no. 5, pp. 629-636, 1996.

[136] H. L. Chen, D. Gabrilovich, A. Virman et al., "Structural and functional analysis of $\beta 2$ microglobulin abnormalities in human lung and breast cancer," International Journal of Cancer, vol. 67, no. 6, pp. 756-763, 1996.

[137] H. L. Chen, D. Gabrilovich, R. Tampé, K. R. Girgis, S. Nadaf, and D. P. Carbone, "A functionally defective allele of TAP1 results in loss of MHC class I antigen presentation in a human lung cancer," Nature Genetics, vol. 13, no. 2, pp. 210 213, 1996.

[138] A. Johnsen, J. France, M. S. Sy, and C. V. Harding, "Downregulation of the transporter for antigen presentation, proteasome subunits, and class I major histocompatibility complex in tumor cell lines," Cancer Research, vol. 58, no. 16, pp. 3660-3667, 1998.

[139] M. R. Ruff, W. L. Farrar, and C. B. Pert, "Interferon $\gamma$ and granulocyte/macrophage colony-stimulating factor inhibit growth and induce antigens characteristic of myeloid differentiation in small-cell lung cancer cell lines," Proceedings of the National Academy of Sciences of the United States of America, vol. 83, no. 17, pp. 6613-6617, 1986.

[140] C. Traversari, R. Meazza, M. Coppolecchia et al., "IFN- $\gamma$ gene transfer restores HLA-class I expression and MAGE-3 antigen 
presentation to CTL in HLA-deficient small cell lung cancer," Gene Therapy, vol. 4, no. 10, pp. 1029-1035, 1997.

[141] G. M. Marley, L. A. Doyle, J. V. Ordonez, A. Sisk, A. Hussain, and R. W. Chiu Yen, "Potentiation of interferon induction of class I major histocompatibility complex antigen expression of human tumor necrosis factor in small cell lung cancer cell lines," Cancer Research, vol. 49, no. 22, pp. 6232-6236, 1989.

[142] C. Garrido, I. Romero, E. Berruguilla et al., "Immunotherapy eradicates metastases with reversible defects in MHC class I expression," Cancer Immunology, Immunotherapy, vol. 60, no. 9, pp. 1257-1268, 2011.

[143] E. Kikuchi, K. Yamazaki, E. Nakayama et al., "Prolonged survival of patients with lung adenocarcinoma expressing XAGE-1b and HLA class I antigens," Cancer Immunity, vol. 8, article 13, 2008.

[144] F. Aladin, G. Lautscham, E. Humphries, J. Coulson, and N. Blake, "Targeting tumour cells with defects in the MHC Class I antigen processing pathway with $\mathrm{CD}^{+} \mathrm{T}$ cells specific for hydrophobic TAP- and Tapasin-independent peptides: the requirement for directed access into the ER," Cancer Immunology, Immunotherapy, vol. 56, no. 8, pp. 1143-1152, 2007.

[145] E. Kikuchi, K. Yamazaki, T. Torigoe et al., "HLA class I antigen expression is associated with a favorable prognosis in early stage non-small cell lung cancer," Cancer Science, vol. 98, no. 9, pp. 1424-1430, 2007.

[146] N. Rouas-Freiss, P. Moreau, S. Ferrone, and E. D. Carosella, "HLA-G proteins in cancer: do they provide tumor cells with an escape mechanism?" Cancer Research, vol. 65, no. 22, pp. 10139-10144, 2005.

[147] G. Pietra, C. Romagnani, C. Manzini, L. Moretta, and M. C. Mingari, "The emerging role of HLA-E-restricted CD8 ${ }^{+} \mathrm{T}$ lymphocytes in the adaptive immune response to pathogens and tumors," Journal of Biomedicine and Biotechnology, vol. 2010, Article ID 907092, 8 pages, 2010.

[148] A. Lin, X. Zhang, Y. Y. Ruan, Q. Wang, W. J. Zhou, and W. H. Yan, "HLA-F expression is a prognostic factor in patients with non-small-cell lung cancer," Lung Cancer, vol. 74, no. 3, pp. 504-509, 2011.

[149] C. Pangault, G. Le Friec, S. Caulet-Maugendre et al., "Lung macrophages and dendritic cells express HLA-G molecules in pulmonary diseases," Human Immunology, vol. 63, no. 2, pp. 83-90, 2002.

[150] M. Urosevic, M. O. Kurrer, J. Kamarashev et al., "Human leukocyte antigen $\mathrm{G}$ up-regulation in lung cancer associates with high-grade histology, human leukocyte antigen class I loss and interleukin-10 production," American Journal of Pathology, vol. 159, no. 3, pp. 817-824, 2001.

[151] S. M. Yie, H. Yang, S. R. Ye, K. Li, D. D. Dong, and X. M. Lin, "Expression of human leucocyte antigen G (HLA-G) is associated with prognosis in non-small cell lung cancer," Lung Cancer, vol. 58, no. 2, pp. 267-274, 2007.

[152] P. Schütt, B. Schütt, M. Switala et al., "Prognostic relevance of soluble human leukocyte antigen-G and total human leukocyte antigen class I molecules in lung cancer patients," Human Immunology, vol. 71, no. 5, pp. 489-495, 2010.

[153] V. Ristich, S. Liang, W. Zhang, J. Wu, and A. Horuzsko, "Tolerization of dendritic cells by HLA-G," European Journal of Immunology, vol. 35, no. 4, pp. 1133-1142, 2005.

[154] M. Allard, R. Oger, V. Vignard et al., "Serum soluble HLA$\mathrm{E}$ in Melanoma: a new potential immune-related marker in cancer," PLoS ONE, vol. 6, no. 6, article e21118, 2011.

[155] S. Nagata, "Apoptosis by death factor," Cell, vol. 88, no. 3, pp. 355-365, 1997.
[156] M. L. Janmaat, F. A. E. Kruyt, J. A. Rodriguez, and G. Giaccone, "Response to epidermal growth factor receptor inhibitors in non-small cell lung cancer cells: limited antiproliferative effects and absence of apoptosis associated with persistent activity of extracellular signal-regulated kinase or Akt kinase pathways," Clinical Cancer Research, vol. 9, no. 6, pp. 2316-2326, 2003.

[157] G. A. Niehans, T. Brunner, S. P. Frizelle et al., "Human lung carcinomas express Fas ligand," Cancer Research, vol. 57, no. 6, pp. 1007-1012, 1997.

[158] N. P. Restifo, "Not so Fas: re-evaluating the mechanisms of immune privilege and tumor escape," Nature Medicine, vol. 6, no. 5, pp. 493-495, 2000.

[159] Y. Zhang, Q. Liu, M. Zhang, Y. Yu, X. Liu, and X. Cao, "Fas signal promotes lung cancer growth by recruiting myeloidderived suppressor cells via cancer cell-derived PGE," Journal of Immunology, vol. 182, no. 6, pp. 3801-3808, 2009.

[160] R. M. Pitti, S. A. Marsters, D. A. Lawrence et al., "Genomic amplification of a decoy receptor for Fas ligand in lung and colon cancer," Nature, vol. 396, no. 6712, pp. 699-703, 1998.

[161] G. G. Gomez and C. A. Kruse, "Mechanisms of malignant glioma immune resistance and sources of immunosuppression," Gene Therapy and Molecular Biology, vol. 10, no. 1, pp. 133-146, 2006.

[162] M. J. Hickey, C. C. Malone, K. L. Erickson et al., "Cellular and vaccine therapeutic approaches for gliomas," Journal of Translational Medicine, vol. 8, article 100, 2010.

[163] L. Ge, N. Hoa, D. A. Bota, J. Natividad, A. Howat, and M. R. Jadus, "Immunotherapy of brain cancers: the past, the present, and future directions," Clinical and Developmental Immunology, vol. 2010, Article ID 296453, 19 pages, 2010.

[164] D. L. Lamm, D. E. Thor, S. C. Harris et al., "Bacillus Calmette-Guerin immunotherapy of superficial bladder cancer," Journal of Urology, vol. 124, no. 1, pp. 38-42, 1980.

[165] J. W. Millar, P. Roscoe, and S. J. Pearce, "Five-year results of a controlled study of BCG immunotherapy after surgical resection in bronchogenic carcinoma," Thorax, vol. 37, no. 1, pp. 57-60, 1982.

[166] J. J. Patard, F. Saint, F. Velotti, C. C. Abbou, and D. K. Chopin, "Immune response following intravesical bacillus CalmetteGuerin instillations in superficial madder cancer: a review," Urological Research, vol. 26, no. 3, pp. 155-159, 1998.

[167] H. M. Jansen, G. C. De Gast, and M. T. Esselink, "Adjuvant immunotherapy with BCG in squamous-cell bronchial carcinoma. Immunereactivity in relation to immunostimulation (preliminary results in a controlled trial)," Thorax, vol. 33, no. 4, pp. 429-438, 1978.

[168] M. Kaufmann, J. Stjernsward, and A. Zimmermann, "Adverse effect of intrapleural Corynebacterium parvum as adjuvant therapy in resected Stage I and II non-small cell carcinoma of the lung," Journal of Thoracic and Cardiovascular Surgery, vol. 89, no. 6, pp. 842-847, 1985.

[169] M. E. R. O’Brien, H. Anderson, E. Kaukel et al., "SRL 172 (killed Mycobacterium vaccae) in addition to standard chemotherapy improves quality of life without affecting survival, in patients with advanced non-small-cell lung cancer: phase III results," Annals of Oncology, vol. 15, no. 6, pp. 906-914, 2004.

[170] J. L. Stanford, C. A. Stanford, M. E. R. O’Brien, and J. M. Grange, "Successful immunotherapy with Mycobacterium vaccae in the treatment of adenocarcinoma of the lung," European Journal of Cancer, vol. 44, no. 2, pp. 224-227, 2008.

[171] A. Hollinshead, T. H. M. Stewart, H. Takita, M. Dalbow, and J. Concannon, "Adjuvant specific active lung cancer 
immunotherapy trials. Tumor-associated antigens," Cancer, vol. 60, no. 6, pp. 1249-1262, 1987.

[172] A. Forero, R. F. Meredith, M. B. Khazaeli et al., "Phase I study of 90Y-CC49 monoclonal antibody therapy in patients with advanced non-small cell lung cancer: effect of chelating agents and paclitaxel co-administration," Cancer Biotherapy and Radiopharmaceuticals, vol. 20, no. 5, pp. 467-478, 2005.

[173] S. C. Grant, M. G. Kris, A. N. Houghton, and P. B. Chapman, "Long survival of patients with small cell lung cancer after adjuvant treatment with the anti-idiotypic antibody BEC2 plus Bacillus Calmette- Guerin," Clinical Cancer Research, vol. 5, no. 6, pp. 1319-1323, 1999.

[174] A. M. Hernández, D. Toledo, D. Martínez et al., "Characterization of the antibody response against NeuGcGM3 ganglioside elicited in non-small cell lung cancer patients immunized with an anti-idiotype antibody," Journal of Immunology, vol. 181, no. 9, pp. 6625-6634, 2008.

[175] L. Arnould, M. Gelly, F. Penault-Llorca et al., "Trastuzumabbased treatment of HER2-positive breast cancer: an antibody-dependent cellular cytotoxicity mechanism?" British Journal of Cancer, vol. 94, no. 2, pp. 259-267, 2006.

[176] S. Shak, "Overview of the trastuzumab (Herceptin) antiHER2 monoclonal antibody clinical program in HER2overexpressing metastatic breast cancer," Seminars in Oncology, vol. 26, no. 4, pp. 71-77, 1999.

[177] E. A. Grimm, A. Mazumder, H. Z. Zhang, and S. A. Rosenberg, "Lymphokine-activated killer cell phenomenon. Lysis of natural killer-resistant fresh solid tumor cells by interleukin 2-activated autologous human peripheral blood lymphocytes," Journal of Experimental Medicine, vol. 155, no. 6, pp. 1823-1841, 1982.

[178] S. A. Rosenberg, M. T. Lotze, L. M. Muul et al., "Observations on the systemic administration of autologous lymphokineactivated killer cells and recombinant interleukin-2 to patients with metastatic cancer," The New England Journal of Medicine, vol. 313, no. 23, pp. 1485-1492, 1985.

[179] S. A. Rosenberg, M. T. Lotze, J. C. Yang et al., "Prospective randomized trial of high-dose interleukin-2 alone or in conjunction with lymphokine-activated killer cells for the treatment of patients with advanced cancer," Journal of the National Cancer Institute, vol. 85, no. 8, pp. 622-632, 1993.

[180] M. Al-Moundhri, M. O'Brien, and B. E. Souberbielle, "Immunotherapy in lung cancer," British Journal of Cancer, vol. 78, no. 3, pp. 282-288, 1998.

[181] J. H. Schiller, C. Morgan-Ihrig, and M. L. Levitt, "Concomitant administration of interleukin-2 plus tumor necrosis factor in advanced non-small cell lung cancer," American Journal of Clinical Oncology, vol. 18, no. 1, pp. 47-51, 1995.

[182] M. Scudeletti, G. Filaci, M. A. Imro et al., "Immunotherapy with intralesional and systemic interleukin-2 of patients with non-small-cell lung cancer," Cancer Immunology Immunotherapy, vol. 37, no. 2, pp. 119-124, 1993.

[183] S. A. Rosenberg, P. Spiess, and R. Lafreniere, "A new approach to the adoptive immunotherapy of cancer with tumorinfiltrating lymphocytes," Science, vol. 233, no. 4770, pp. 1318-1321, 1986.

[184] G. Melioli, G. B. Ratto, M. Ponte et al., "Treatment of stage IIIB non-small-cell lung cancer with surgery followed by infusion of tumor infiltrating lymphocytes and recombinant interleukin-2: a pilot study," Journal of Immunotherapy, vol. 19, no. 3, pp. 224-230, 1996.

[185] M. Meta, M. Ponte, M. Gustella et al., "Detection of oligoclonal $\mathrm{T}$ lymphocytes in lymph nodes draining from advanced non-small cell lung cancer," Cancer Immunology Immunotherapy, vol. 40, no. 4, pp. 235-240, 1995.

[186] M. E. Dudley, J. R. Wunderlich, J. C. Yang et al., "Adoptive cell transfer therapy following non-myeloablative but lymphodepleting chemotherapy for the treatment of patients with refractory metastatic melanoma," Journal of Clinical Oncology, vol. 23, no. 10, pp. 2346-2357, 2005.

[187] L. Gattinoni, D. J. Powell Jr., S. A. Rosenberg, and N. P. Restifo, "Adoptive immunotherapy for cancer: building on success," Nature Reviews Immunology, vol. 6, no. 5, pp. 383393, 2006.

[188] P. Wrobel, H. Shojaei, B. Schittek et al., "Lysis of a broad range of epithelial tumour cells by human $\gamma \delta \mathrm{T}$ cells: involvement of NKG2D ligands and T-cell receptor- versus NKG2D-dependent recognition," Scandinavian Journal of Immunology, vol. 66, no. 2-3, pp. 320-328, 2007.

[189] V. Groh, R. Rhinehart, H. Secrist, S. Bauer, K. H. Grabstein, and T. Spies, "Broad tumor-associated expression and recognition by tumor-derived $\gamma \delta$ T cells of MICA and MICB," Proceedings of the National Academy of Sciences of the United States of America, vol. 96, no. 12, pp. 6879-6884, 1999.

[190] J. Nakajima, T. Murakawa, T. Fukami et al., "A phase I study of adoptive immunotherapy for recurrent non-small-cell lung cancer patients with autologous $\gamma \delta$ T cells," European Journal of Cardio-thoracic Surgery, vol. 37, no. 5, pp. 11911197, 2010.

[191] G. Dranoff, E. Jaffee, A. Lazenby et al., "Vaccination with irradiated tumor cells engineered to secrete murine granulocytemacrophage colony-stimulating factor stimulates potent, specific, and long-lasting anti-tumor immunity," Proceedings of the National Academy of Sciences of the United States of America, vol. 90, no. 8, pp. 3539-3543, 1993.

[192] R. Salgia, T. Lynch, A. Skarin et al., "Vaccination with irradiated autologous tumor cells engineered to secrete granulocyte-macrophage colony-stimulating factor augments antitumor immunity in some patients with metastatic non-small-cell lung carcinoma," Journal of Clinical Oncology, vol. 21, no. 4, pp. 624-630, 2003.

[193] J. Nemunaitis, D. Sterman, D. Jablons et al., "Granulocytemacrophage colony-stimulating factor gene-modified autologous tumor vaccines in non-small-cell lung cancer," Journal of the National Cancer Institute, vol. 96, no. 4, pp. 326-331, 2004.

[194] J. Nemunaitis, T. Jahan, H. Ross et al., "Phase 1/2 trial of autologous tumor mixed with an allogeneic GVAX vaccine in advanced-stage non-small-cell lung cancer," Cancer Gene Therapy, vol. 13, no. 6, pp. 555-562, 2006.

[195] L. E. Raez, P. A. Cassileth, J. J. Schlesselman et al., "Allogeneic vaccination with a B7.1 HLA-A gene-modified adenocarcinoma cell line in patients with advanced non-small-cell lung cancer," Journal of Clinical Oncology, vol. 22, no. 14, pp. 28002807, 2004.

[196] H. Hörig, D. S. Lee, W. Conkright et al., "Phase I clinical trial of a recombinant canarypoxvirus (ALVAC) vaccine expressing human carcinoembryonic antigen and the B7.1 costimulatory molecule," Cancer Immunology Immunotherapy, vol. 49, no. 9, pp. 504-514, 2000.

[197] R. A. Madan, M. Bilusic, J. W. Hodge et al., "A phase I trial of a yeast-based therapeutic cancer vaccine targeting CEA," Journal of Clinical Oncology, vol. 29, supplement, abstract no. 2604, 2011.

[198] M. A. Hollingsworth and B. J. Swanson, "Mucins in cancer: protection and control of the cell surface," Nature Reviews Cancer, vol. 4, no. 1, pp. 45-60, 2004. 
[199] R. Ramlau, E. Quoix, J. Rolski et al., "A phase II study of Tg4010 (Mva-Muc1-Il2) in association with chemotherapy in patients with stage III/IV non-small cell lung cancer," Journal of Thoracic Oncology, vol. 3, no. 7, pp. 735-744, 2008.

[200] B. Acres, E. Quoix, R. Ramlau et al., "Biomarkers associated with clinical outcome in advanced non-small cell lung cancer patients treated with TG4010," Journal of Clinical Oncology, vol. 27, no. 15, supplement, abstract no. 3027, 2009.

[201] P. van der Bruggen, V. Stroobant, N. Vigneron, and B. Van den Eynde, "Peptide database," Cancer Immunity, http:// www.cancerimmunity.org/peptidedatabaseTcellepitopes.htm.

[202] M. Palmer, J. Parker, S. Modi et al., "Phase I study of the BLP25 (MUC1 peptide) liposomal vaccine for active specific immunotherapy in stage IIIB/IV non-small-cell lung cancer," Clinical Lung Cancer, vol. 3, no. 1, pp. 49-57, 2001.

[203] Y. Oji, S. Miyoshi, H. Maeda et al., "Overexpression of the Wilms' tumor gene WT1 in de novo lung cancers," International Journal of Cancer, vol. 100, no. 3, pp. 297-303, 2002.

[204] Y. Oka, A. Tsuboi, T. Taguchi et al., "Induction of WT1 (Wilms' tumor gene)-specific cytotoxic T lymphocytes by WT1 peptide vaccine and the resultant cancer regression," Proceedings of the National Academy of Sciences of the United States of America, vol. 101, no. 38, pp. 13885-13890, 2004.

[205] S. Gomi, M. Nakao, F. Niiya et al., "A cyclophilin B gene encodes antigenic epitopes recognized by HLA-A24restricted and tumor-specific CTLs," Journal of Immunology, vol. 163, no. 9, pp. 4994-5004, 1999.

[206] R. Gohara, N. Imai, T. Rikimaru et al., "Phase 1 clinical study of cyclophilin B peptide vaccine for patients with lung cancer," Journal of Immunotherapy, vol. 25, no. 5, pp. 439444, 2002.

[207] J. Vansteenkiste, M. Zielinski, A. Linder et al., "Final results of a multicenter, double-blind, randomized, placebocontrolled phase II study to assess the efficacy of MAGE-A3 immunotherapeutic as adjuvant therapy in stage IB/II nonsmall cell lung cancer," Journal of Clinical Oncology, vol. 25, no. 18, supplement, abstract no. 7554, 2007.

[208] W. Sienel, C. Varwerk, A. Linder et al., "Melanoma associated antigen (MAGE)-A3 expression in Stages I and II non-small cell lung cancer: results of a multi-center study," European Journal of Cardio-thoracic Surgery, vol. 25, no. 1, pp. 131-134, 2004.

[209] V. G. Brichard and D. Lejeune, “GSK's antigen-specific cancer immunotherapy programme: pilot results leading to Phase III clinical development," Vaccine, vol. 25, no. 2, pp. B61-B71, 2007.

[210] M. Barve, J. Bender, N. Senzer et al., "Induction of immune responses and clinical efficacy in a phase II trial of IDM-2101, a 10-epitope cytotoxic T-lymphocyte vaccine, in metastatic non-small-cell lung cancer," Journal of Clinical Oncology, vol. 26, no. 27, pp. 4418-4425, 2008.

[211] S. V. Sharma, D. W. Bell, J. Settleman, and D. A. Haber, "Epidermal growth factor receptor mutations in lung cancer," Nature Reviews Cancer, vol. 7, no. 3, pp. 169-181, 2007.

[212] G. Giaccone and J. A. Rodriguez, "EGFR inhibitors: what have we learned from the treatment of lung cancer?" Nature Clinical Practice Oncology, vol. 2, no. 11, pp. 554-561, 2005.

[213] E. N. Vinageras, A. de La Torre, M. O. Rodríguez et al., "Phase II randomized controlled trial of an epidermal growth factor vaccine in advanced non-small-cell lung cancer," Journal of Clinical Oncology, vol. 26, no. 9, pp. 1452-1458, 2008.

[214] G. González, T. Crombet, E. Neninger, C. Viada, and A. Lage, "Therapeutic vaccination with Epidermal Growth Factor
(EGF) in advanced lung cancer: analysis of pooled data from three clinical trials," Human Vaccines, vol. 3, no. 1, pp. 8-13, 2007.

[215] S. J. Antonia, N. Mirza, I. Fricke et al., "Combination of p53 cancer vaccine with chemotherapy in patients with extensive stage small cell lung cancer," Clinical Cancer Research, vol. 12, no. 3, pp. 878-887, 2006.

[216] I. F. Ciernik, J. A. Berzofsky, and D. P. Carbone, "Human lung cancer cells endogenously expressing mutant p53 process and present the mutant epitope and are lysed by mutant-specific cytotoxic T lymphocytes," Clinical Cancer Research, vol. 2, no. 5, pp. 877-882, 1996.

[217] A. A. Chiappori, H. Soliman, W. E. Janssen, S. J. Antonia, and D. I. Gabrilovich, "INGN-225: a dendritic cell-based p53 vaccine (Ad.p53-DC) in small cell lung cancer: observed association between immune response and enhanced chemotherapy effect," Expert Opinion on Biological Therapy, vol. 10, no. 6, pp. 983-991, 2010.

[218] E. A. Hirschowitz, T. Foody, R. Kryscio, L. Dickson, J. Sturgill, and J. Yannelli, "Autologous dendritic cell vaccines for nonsmall-cell lung cancer," Journal of Clinical Oncology, vol. 22, no. 14 , pp. 2808-2815, 2004.

[219] E. A. Hirschowitz, T. Foody, G. E. Hidalgo, and J. R. Yannelli, "Immunization of NSCLC patients with antigenpulsed immature autologous dendritic cells," Lung Cancer, vol. 57, no. 3, pp. 365-372, 2007.

[220] Q. Zhou, A. L. Guo, C. R. Xu et al., "A dendritic cellbased tumour vaccine for lung cancer: full-length XAGE$1 \mathrm{~b}$ protein-pulsed dendritic cells induce specific cytotoxic $\mathrm{T}$ lymphocytes in vitro," Clinical and Experimental Immunology, vol. 153, no. 3, pp. 392-400, 2008.

[221] S. J. Um, Y. J. Choi, H. J. Shin et al., "Phase I study of autologous dendritic cell tumor vaccine in patients with nonsmall cell lung cancer," Lung Cancer, vol. 70, no. 2, pp. 188194, 2010.

[222] N. Chaput, N. E. C. Schartz, F. André et al., "Exosomes as potent cell-free peptide-based vaccine. II. Exosomes in CpG adjuvants efficiently prime naive Tcl lymphocytes leading totumor rejection," Journal of Immunology, vol. 172, no. 4, pp. 2137-2146, 2004.

[223] E. Segura, S. Amigorena, and C. Théry, "Mature dendritic cells secrete exosomes with strong ability to induce antigenspecific effector immune responses," Blood Cells, Molecules, and Diseases, vol. 35, no. 2, pp. 89-93, 2005.

[224] L. Zitvogel, A. Regnault, A. Lozier et al., "Eradication of established murine tumors using a novel cell-free vaccine: dendritic cell-derived exosomes," Nature Medicine, vol. 4, no. 5, pp. 594-600, 1998.

[225] S. Viaud, C. Théry, S. Ploix et al., "Dendritic cell-derived exosomes for cancer immunotherapy: what's next?" Cancer Research, vol. 70, no. 4, pp. 1281-1285, 2010.

[226] J. Nemunaitis, R. O. Dillman, P. O. Schwarzenberger et al., "Phase II study of belagenpumatucel-L, a transforming growth factor beta-2 antisense gene-modified allogeneic tumor cell vaccine in non-small-cell lung cancer," Journal of Clinical Oncology, vol. 24, no. 29, pp. 4721-4730, 2006.

[227] R. K. Jain, D. G. Duda, J. W. Clark, and J. S. Loeffler, "Lessons from phase III clinical trials on anti-VEGF therapy for cancer," Nature Clinical Practice Oncology, vol. 3, no. 1, pp. 24-40, 2006.

[228] P. Tomasini, N. Khobta, L. Greillier, and F. Barlesi, "Ipilimumab: its potential in non-small cell lung cancer," Therapeutic Advances in Medical Oncology, vol. 4, no. 2, pp. 43-50, 2012. 
[229] F. S. Hodi, S. J. O’Day, D. F. McDermott et al., "Improved survival with ipilimumab in patients with metastatic melanoma," The New England Journal of Medicine, vol. 363, no. 8, pp. 711-723, 2010.

[230] F. Hirano, K. Kaneko, H. Tamura et al., "Blockade of B7$\mathrm{H} 1$ and PD-1 by monoclonal antibodies potentiates cancer therapeutic immunity," Cancer Research, vol. 65, no. 3, pp. 1089-1096, 2005.

[231] H. Dong, S. E. Strome, D. R. Salomao et al., "Tumorassociated B7-H1 promotes T-cell apoptosis: a potential mechanism of immune evasion," Nature Medicine, vol. 8, no. 8, pp. 793-800, 2002.

[232] Y. Iwai, M. Ishida, Y. Tanaka, T. Okazaki, T. Honjo, and N. Minato, "Involvement of PD-L1 on tumor cells in the escape from host immune system and tumor immunotherapy by PD-L1 blockade," Proceedings of the National Academy of Sciences of the United States of America, vol. 99, no. 19, pp. 12293-12297, 2002.

[233] J. A. Brown, D. M. Dorfman, F. R. Ma et al., "Blockade of programmed death-1 ligands on dendritic cells enhances T cell activation and cytokine production," Journal of Immunology, vol. 170, no. 3, pp. 1257-1266, 2003.

[234] J. Konishi, K. Yamazaki, M. Azuma, I. Kinoshita, H. DosakaAkita, and M. Nishimura, "B7-H1 expression on nonsmall cell lung cancer cells and its relationship with tumorinfiltrating lymphocytes and their PD-1 expression," Clinical Cancer Research, vol. 10, no. 15, pp. 5094-5100, 2004.

[235] I. Perrot, D. Blanchard, N. Freymond et al., "Dendritic cells infiltrating human non-small cell lung cancer are blocked at immature stage," Journal of Immunology, vol. 178, no. 5, pp. 2763-2769, 2007.

[236] Y. Sun, Y. Wang, J. Zhao et al., "B7-H3 and B7-H4 expression in non-small-cell lung cancer," Lung Cancer, vol. 53, no. 2, pp. 143-151, 2006.

[237] I. H. Choi, G. Zhu, G. L. Sica et al., "Genomic Organization and Expression Analysis of B7-H4, an Immune Inhibitory Molecule of the B7 Family," Journal of Immunology, vol. 171, no. 9, pp. 4650-4654, 2003.

[238] J. Dannull, Z. Su, D. Rizzieri et al., "Enhancement of vaccine-mediated antitumor immunity in cancer patients after depletion of regulatory T cells," Journal of Clinical Investigation, vol. 115, no. 12, pp. 3623-3633, 2005.

[239] A. J. Rech, R. Mick, A. Recio et al., "Phase I study of antiCD25 mab daclizumab to deplete regulatory $\mathrm{T}$ cells prior to telomerase/survivin peptide vaccination in patients (pts) with metastatic breast cancer (MBC)," Journal of Clinical Oncology, vol. 28, no. 15, supplement, abstract no. 2508, 2010. 


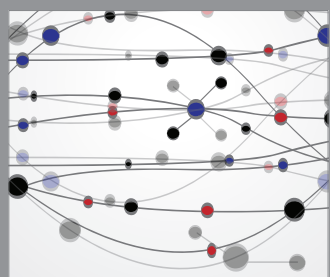

The Scientific World Journal
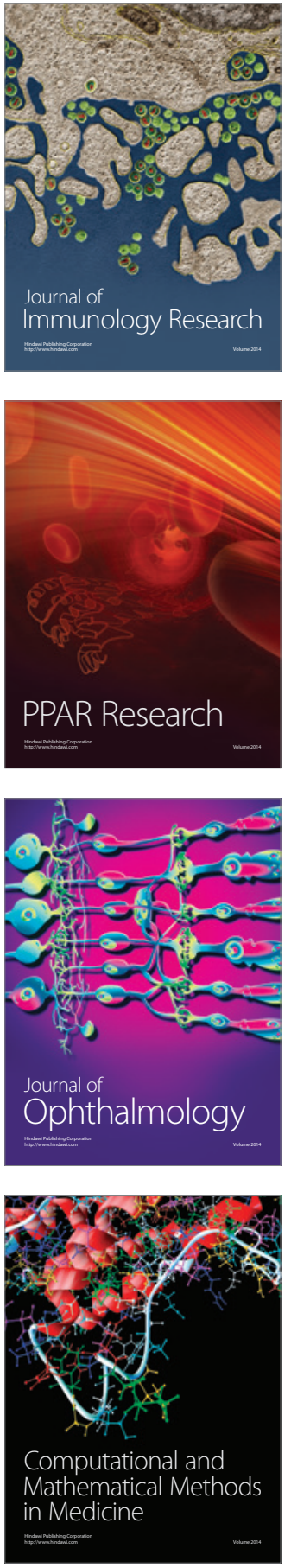

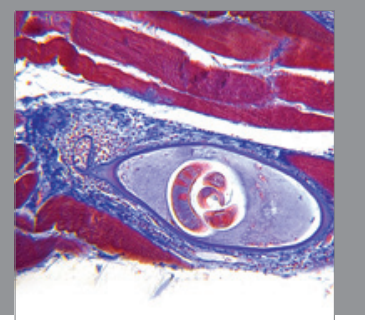

Gastroenterology

Research and Practice
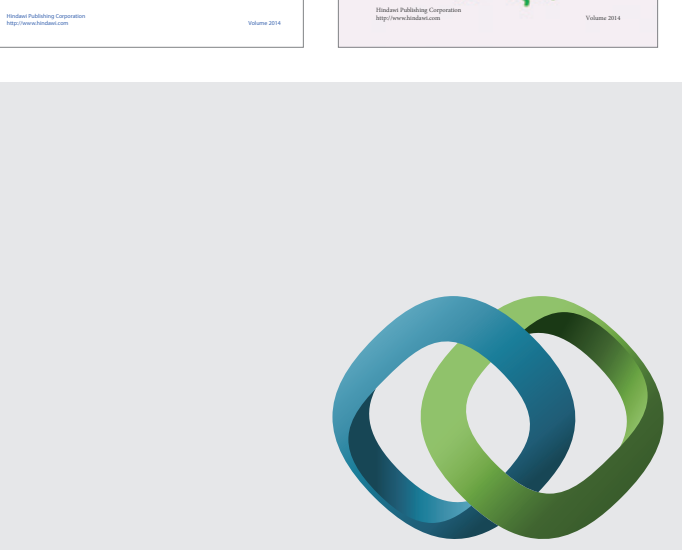

\section{Hindawi}

Submit your manuscripts at

http://www.hindawi.com
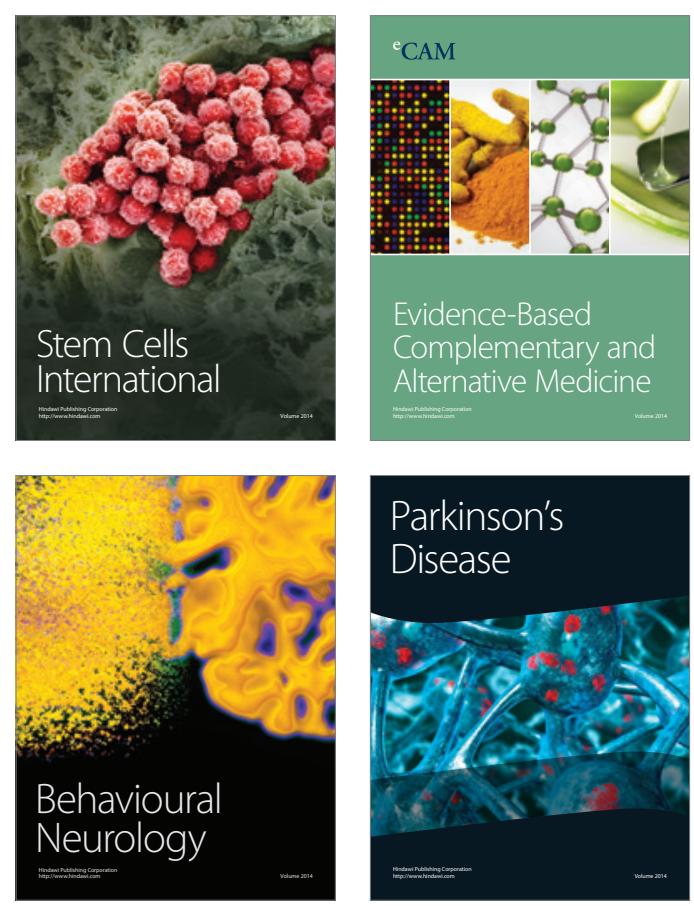

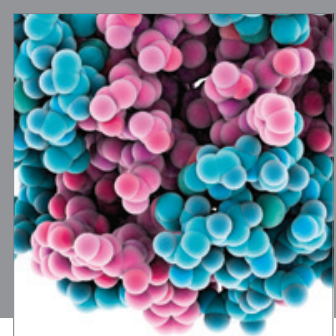

Journal of
Diabetes Research

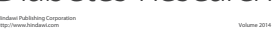

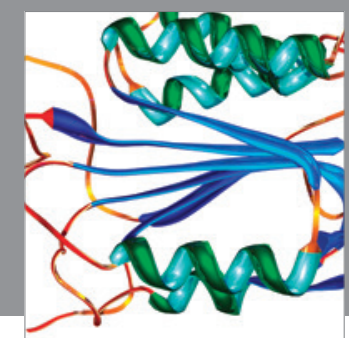

Disease Markers
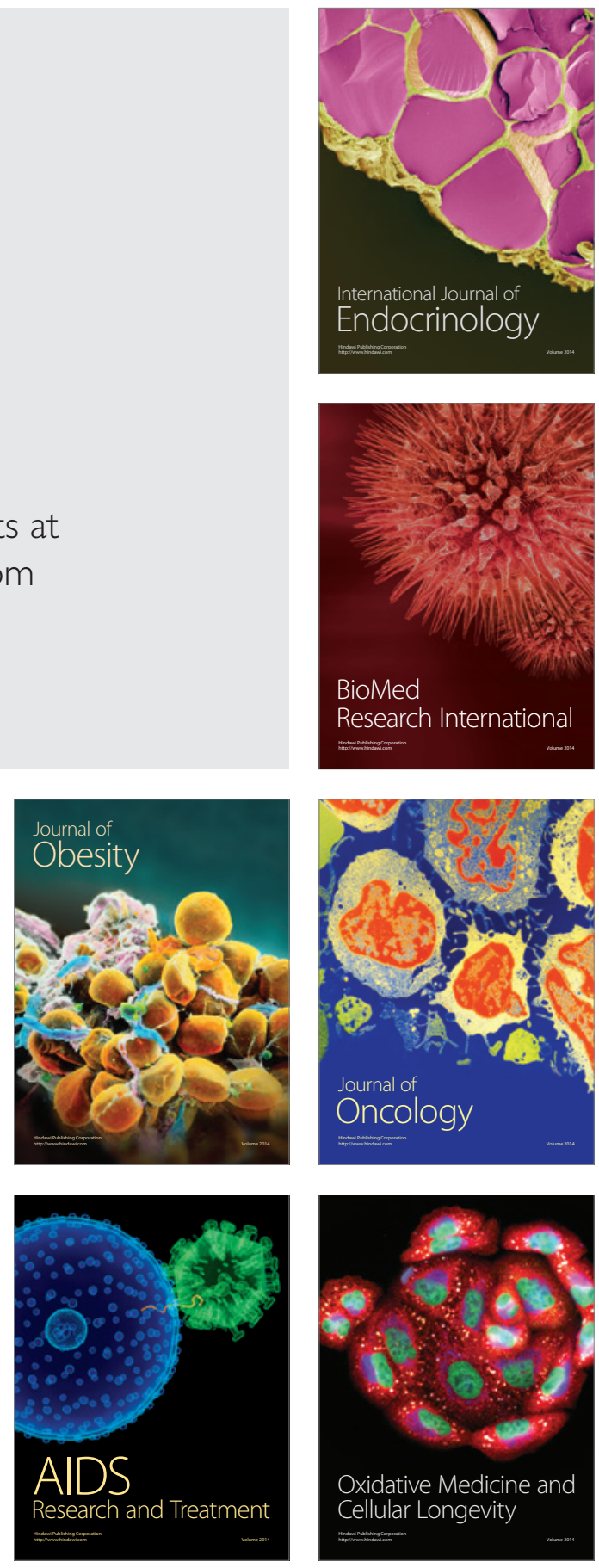